\title{
Measuring the vulnerability of marine social-ecological systems: a prerequisite for the identification of climate change adaptations
}

\author{
Sarah J. Metcalf ${ }^{1}$, Elizabeth I. van Putten ${ }^{2,3}$, Stewart Frusher $^{3,4}$, Nadine A. Marshall $^{5}, \underline{\text { Malcolm Tull }}^{1}$, Nick Caputi ${ }^{6}$, Marcus Haward \\ ${ }^{3,4}$ Alistair J. Hobdav $^{3,7}, \underline{\text { Neil J. Holbrook }}^{3,4}$ Sarah M. Jennings $^{3,8}$, Gretta T. Pecl $^{3,4}$ and Jenny Shaw $^{9}$
}

\begin{abstract}
Reducing the vulnerability of coastal communities to marine climate change requires that communities have some intrinsic capacity to adapt. To assist adaptation planning and the implementation of adaptation strategies, identifying barriers and enablers to adaptation is important. Adaptive capacity, resource dependence, local climate change exposure and biological sensitivity were used to assess socioeconomic vulnerability to climate change in three Australian coastal communities: St Helens, Tasmania; Bowen, Queensland; and Geraldton, Western Australia. Higher adaptive capacity was associated with larger population size (i.e., Geraldton) whereas greater resource dependence, and lower human and natural capital were associated with smaller populations (St Helens and Bowen). Socioeconomic vulnerability was greatly influenced by climate exposure and sensitivity with the moderately sized Bowen having the highest socioeconomic vulnerability to climate change. Adaptation strategies that utilized available assets, improved adaptive capacity, or reduced socioeconomic vulnerability were identified in partnership with local communities, including increased and diversified employment opportunities, the re-establishment of local fish markets, and improved education and communication. The level of resources, or "capitals," available to communities can indicate where barriers and enablers to adaptation exist. Identified barriers to adaptation included a heavy reliance on one sector for employment and a lack of physical capital. We demonstrate that knowledge of intrinsic community characteristics can be beneficial for prioritizing adaptation actions to reduce socioeconomic vulnerability to marine climate change.
\end{abstract}

Key Words: adaptive capacity; coastal communities; fisheries; resource dependency; social-ecological

\section{INTRODUCTION}

More than $85 \%$ of the Australian population lives within $50 \mathrm{~km}$ of the coast, with settlements ranging from small towns to major cities (ABS 2003). These coastal residents have many connections with the sea, supporting livelihoods that include commercial fishing and aquaculture, coastal management, retail, industry, transport, tourism, and recreation. Small coastal communities, defined here as having populations of less than 30,000 people and located directly adjacent to the ocean, are exposed to climate change through various impacts such as changes in the productivity of commercial and recreational fisheries (Roessig et al. 2004, Hobday et al. 2008, Marshall et al. 2013, Holbrook and Johnson 2014) and aquaculture (Brander 2007, Spillman and Hobday 2014), damage to infrastructure (McAllister et al. 2014), and alterations to tourist visitation (Wall 1998). Climate change impacts go beyond those that are purely economic and include the impacts on spiritual and cultural connections to the sea, for instance, for indigenous people (e.g., McNiven 2004) and the wider community (e.g., Costanza et al. 1997). Many of these potential impacts are well-documented and the term "climate change," although still debated in some circles, is now part of the general vocabulary (Hulme 2009). However, there is still a lack of understanding of the mechanisms by which local impacts can manifest and flow through a coastal community (Barnett et al. 2014). For example, how will a decline in commercial fisheries impact the broader community or how will the community be affected if infrastructure such as, hospitals, ports, or sewerage plants are inundated by an extreme storm surge? Related to this lack of knowledge is the perception that climate change is a long- term risk and can be dealt with in the future when more information is available (Barnett et al. 2014). Climate change is also perceived as a remote risk, removed from direct personal experience (Bord et al. 1998, Kirby 2004, Hodgkinson et al. 2014), which potentially reduces the incentive to act. However, the economic and social cost to government and local communities from dealing with actual impacts of climate change may be very high (OECD 2010, McAllister et al. 2014) and efforts to implement adaptation strategies earlier rather than later may reduce these costs in the future (Stafford-Smith et al. 2011). Anticipating potential change through the early implementation of adaptation strategies can therefore be cost-effective and may provide current as well as future benefits for businesses and communities (Holbrook and Johnson 2014, Spillman and Hobday 2014).

Most Australian coastal communities are located close to commercial fishing grounds and have traditionally been referred to as "fishing towns." Many of these communities have recently experienced widespread declines in the commercial fishing industry in conjunction with changes in demographics and migration. For example, in some coastal communities the immigration of retiree baby-boomers as part of the so-called "seachange phenomenon" has substantially changed the structure of these communities (Burnley and Murphy 2002, Gurran and Blakely 2007). The focus of economic activities in coastal communities is shifting away from fishing and toward alternative activities such as aquaculture, tourism, and mining (van Putten et al. 2014). Such changes are expected to alter the capacity of

${ }^{1}$ School of Management and Governance, Murdoch University, ${ }^{2} \mathrm{CSIRO}$ Oceans and Atmosphere,Hobart, Australia, ${ }^{3} \mathrm{Centre}$ for Marine Socioecology, University of Tasmania, ${ }^{4}$ Institute for Marine and Antarctic Studies, University of Tasmania, ${ }^{5}$ CSIRO Land and Water Flagship, ${ }^{6}$ Department of Fisheries, Western Australia, ${ }^{7}$ CSIRO Oceans and Atmosphere Flagship, ${ }^{8}$ Tasmanian School of Business and Economics, University of Tasmania, ${ }^{9}$ Curtin University Sustainability Policy Institute 
each community to adapt to climate change through alternative employment options or other economic opportunities.

The demographic characteristics of communities can influence their ability to adapt. For example, larger population centers may be better able to buffer the impacts of change and absorb the costs associated with adaptation. On the other hand, adaptation in larger populations may be hindered by the inertia that is characteristic of larger populations (Pihkala et al. 2007). In this study, three coastal communities of differing demography and experiencing different climate change impacts are used to examine the role of resource dependence and coastal community demographics in influencing the capacity to adapt, or the potential to cope with and adapt to climate change. A key outcome is the measurement and assessment of adaptive capacity and socioeconomic vulnerability to marine climate change impacts in these coastal communities. Although we have focused on coastal communities in Australia, by using the relevant data similar methods can be applied to different geopolitical areas, e.g., local government areas, states, and countries.

Sensitivity and exposure to climate change impacts are central factors in determining the vulnerability (as defined by, for instance, Adger 2006) of a community and the scope of adaptation required. Vulnerability assessments can adopt different perspectives with respect to vulnerability, for example, taking a risk-hazard approach (e.g., Armitage and Plummer 2010, Renn et al. 2011), sustainable livelihood approach (SLA; Scoones 1998), or resilience approach (Folke 2006). In this study we have combined the basic vulnerability framework (e.g., IPCC 2001, FAO 2013, Marshall et al. 2013) and the livelihood analysis (Allison and Horemans 2006). We use the codependency framework of Marshall et al. (2013) to assess climate-sensitive social-ecological systems, where the vulnerability of the ecological system is intrinsically linked to that of the socioeconomic system. Using this framework, a holistic assessment of both the socioeconomic vulnerability and adaptive capacity of communities can be undertaken. Such a framework is important to be able to investigate how adaptive capacity and vulnerability affects the ability of Australian coastal communities to implement adaptation strategies and identify potential barriers to implementation.

We have developed a metric to determine community socialecological vulnerability to climate change using a SLA, and the identification of SLA capitals (as a measure of adaptive capacity), resource dependence, and climate exposure metrics. Adaptation strategies have been identified through discussion with community members and experts. Barriers and enablers to the successful implementation of adaptation strategies are identified through the process of calculation. For example, a barrier to the implementation of adaptations may arise through a capital that is particularly lacking in one community while an enabler may arise though low resource dependence and a diversity of local industries. Trade-offs between different assets, e.g., social networks, financial resources, or education levels, and between short and long-term goals are discussed in relation to the constraints they can pose for the successful implementation of adaptations (Farrington et al. 1999, Adger et al. 2009).

\section{Adaptation and the capacity to adapt}

Having the capacity to adapt is essential to successfully implement adaptation strategies. Adaptive capacity reflects the potential or preconditions necessary to cope with change and enable adaptation without limiting opportunities for the future (Brooks and Adger 2005, Nelson et al. 2007). It is essentially the capacity to convert current resources, whether financial, physical, social, or other, into successful adaptations (Adger et al. 2003). Characteristics such as the ability to learn, the flexibility to experiment and adopt novel solutions, and the ability to respond generally to a broad range of challenges all contribute to adaptive capacity (Gunderson 2000, Armitage 2005, Darnhofer et al. 2010, Marshall et al. 2012). At the individual level, the effective management of risk and uncertainty is fundamental for coping and adapting to change (Ritchie et al. 2004, Taylor 2003, NurseyBray et al. 2012), and the presence of financial and emotional buffers enable individuals to absorb the costs of change and to adapt (Lawes and Kingwell 2012, Marshall et al. 2012). Similarly, skills to effectively plan, experiment, learn, and reorganize allow individuals to be proactive to the impacts of climate change while individuals that have a greater interest in adaptation are more likely to effectively identify the consequences, impacts, and possible responses to climate change (Howden et al. 2007).

The contribution of individual level SLA capitals to adaptive capacity has been illustrated through theoretical and empirical research findings (e.g., Marshall et al. 2012), but the identification of trade-offs and substitution between the SLA capitals is highly context specific (e.g., Elrick-Barr et al. 2014). For instance, at the individual level strong human capital, e.g., a high level of education, may not be a substitute for a lack of financial capital (to increase the height of a sea wall to protect against sea level rise). To better understand the interventions necessary for enhancing individual and community adaptive capacity, it is important to also understand pathways by which the enhancement can take place (Elrick-Barr et al. 2014), such as via education or financial support.

In addition to complexities associated with substitution between capitals, findings at the individual level cannot be simply aggregated to a broader scale, e.g., the community level. However, adaptation at the individual scale is likely to influence adaptation at broader scales (Adger et al. 2013) such as the level of a coastal community. For example, the success of a community-led or industry-led initiative may depend on the support and capacity of individuals (Marshall et al. 2012). Individuals that have a higher capacity to incorporate change into their working lives are more likely to effectively trade-off the short-term costs of change and future limitations on productivity (Marshall et al. 2011). For these people, change may not be seen as a disturbance, but as an opportunity for the reorganization of resources, and for the renewal of their business's organization and activities (Darnhofer et al. 2010). This individual capacity will contribute toward the success of their industry and consequently the ability of the community to cope with and adapt to climate change.

The capacity for individuals and communities to adapt to climate change is also related to resource access (Adger et al. 2003) and availability (Ellis 2000). However, individuals or communities with similar resources may not adapt to climate change with equal success because they can use the resources in varying ways 
resulting in different adaptive outcomes (Marshall et al. 2011). Empirical evidence suggests that adaptation is highly contextspecific (Risbey et al. 1999, Wolf 2011) and the resource levels of different communities must be understood to gauge adaptive capacity. In some situations, higher average age is correlated to greater social capital (Wolf 2011) that can, in turn, indicate higher levels of social learning, experimentation, and strategic skills sets. A high level of dependence on marine industries for employment, such as fisheries or aquaculture, may reduce community resilience and adaptive capacity (McLeman et al. 2011) in the marine environment, especially in the face of extreme events, climate change, and other simultaneous impacts, such as invasive species or illegal fishing (Marshall et al. 2013, Holbrook and Johnson 2014, Hodgkinson et al. 2014)

Adaptation at both an individual and community level has to be considered in context, including the institutional specifics and the policies, laws, and regulations that influence potential and actual adaptive capacity (e.g., Tompkins and Adger 2004). Institutional commitment to addressing climate change issues, and the power relationships among the various institutions (e.g., De Haan 2012) operating at local, state, national, and global scales (Elrick-Barr et al. 2014), will strongly influence individual and community capacity to adapt and ultimately the actual adaptations that are put in place (e.g. Adger et al. 2005).

A livelihoods (SLA) or capitals framework (Scoones 1998) offers an inductive and intuitively accessible approach to assessing diverse drivers of adaptive capacity and resilience (Ellis 2000, Brown et al. 2010). SLA can make meaningful use of secondary datasets to assess the status and trends of livelihood assets in the context of environmental, economic, and social impacts on these assets. The policy and institutional context within which these capitals exist can form boundary conditions for analysis of adaptive capacity. Thus, adaptation strategies that address any vulnerability in the socioeconomic and ecological system can be designed. The capitals framework distinguishes between five types of capital, human, social, physical, natural, and financial, and allows for the calculation and categorization of adaptive capacity. Even though the SLA approach has been critiqued for being very local in focus it is a useful approach to illustrate differences between regions and allows comparison between them. The five capitals comprise the following (modified from Scoones 1998):

- Human capital: all things that allow a person to pursue a sustainable livelihood such as skills, health (including mental), and education that contribute to the productivity of labor and capacity to manage natural resources, e.g., fisheries.

- Social capital: the social bonds, e.g., family networks or volunteer groups, that facilitate cooperative action, and the social bridging and linking through which ideas and resources are accessed. Social capital also includes rules, norms, obligations, and trust embedded in social relations, social structures, and societies' institutional arrangements.

- Natural capital: the productivity of natural systems including the water, inorganic, e.g., land or minerals, and biological resources from which rural livelihoods are often derived.
- Physical (private) capital: built capital items, such as a house, owned outright that is used to support livelihoods and the level of self-management in business, i.e., self-employed or business owner/managers.

- Financial capital: the level, variability, and diversity of income sources, and access to other financial resources that together contribute to wealth. For example, cash, savings, access to credit, and convertible assets all contribute to financial capital and are used by people to achieve their livelihood strategies.

In this study the five sustainable livelihoods analysis capitals are used to systematically estimate community adaptive capacity and social-ecological vulnerability to climate change based on readily available Australian Census data. Based on our metrics, we compare and analyze the social-ecological vulnerability metric for three Australian coastal communities.

\section{METHODS}

Case study communities

Australian coastal communities range from coastal regional centres with populations of tens of thousands of residents (e.g., Geraldton, Western Australia; Burnie, Tasmania; Port Lincoln, South Australia) to very small coastal towns ( $<500$ residents, e.g., Port Campbell, Victoria; Beagle Bay, Western Australia; Cape Tribulation, Queensland). We focused on three coastal communities selected to represent a range of population sizes and industries (Table 1): St Helens in Tasmania, Geraldton in Western Australia, and Bowen in Queensland (Fig. 1).

Fig. 1. Map of Australia showing the location of the three case study coastal communities: Geraldton, Western Australia; St Helens, Tasmania; and Bowen, Queensland.

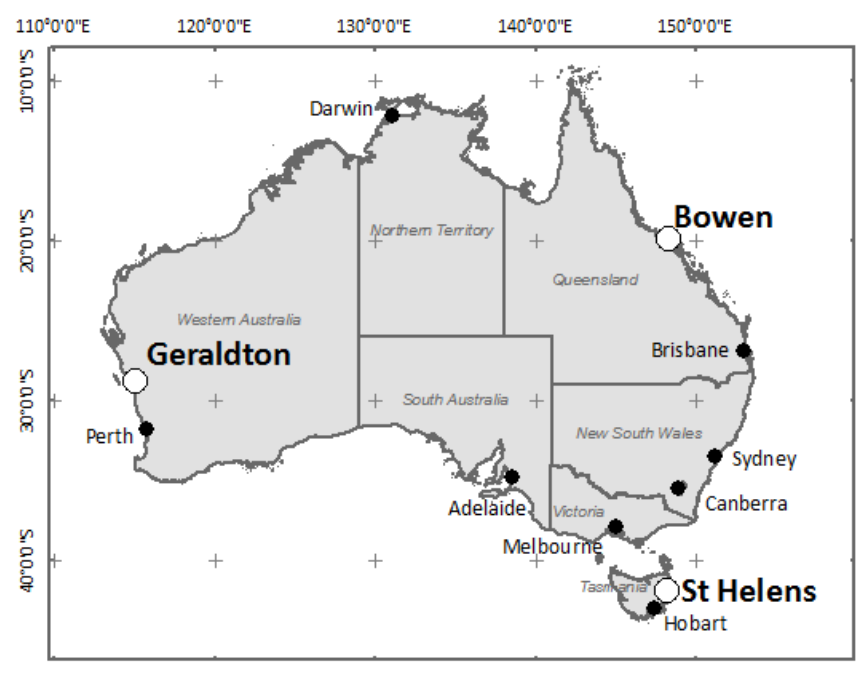

Framework for the calculation of social-ecological vulnerability to marine climate change

The framework for the calculation of adaptive capacity and socialecological vulnerability to climate change is depicted in Figure 2. Following the description of Marshall et al. (2013), social- 
Table 1. General information and demographics (ABS 2011) for three case study areas. NB: Main industries are based on the list provided by the Australian Bureau of Statistics for the 2011 census.

\begin{tabular}{|c|c|c|c|}
\hline Case Study Examples & St Helens, Tasmania & Bowen, Queensland & Geraldton, Western Australia \\
\hline$\overline{\text { Population }}$ & 2000 (ABS 2011). & $10,000(\mathrm{ABS} 2011)$ & 30,000 (ABS 2011). \\
\hline Summer population & $\begin{array}{l}8000-20,000 \text {, includes temporary } \\
\text { "holiday shack owners" and } \\
\text { tourists (personal communication). }\end{array}$ & $\begin{array}{l}\text { NA - does not change substantially } \\
\text { between seasons }\end{array}$ & $\begin{array}{l}\text { NA - does not change substantially } \\
\text { between seasons }\end{array}$ \\
\hline $\begin{array}{l}\text { Population working age } \\
\text { (between } 25-54 \text { years) }\end{array}$ & $\begin{array}{l}35 \% \text { (declined between } 2001 \text { and } \\
2006 \text { ). }\end{array}$ & $40 \%$ & $40 \%$ \\
\hline $\begin{array}{l}\text { Population over } 65 \text { years of } \\
\text { age }\end{array}$ & $21 \%$ & $15 \%$ & $12 \%$ \\
\hline Three largest industries & Timber, fishing, tourism & Agriculture, tourism, mining & Mining, agriculture, fishing \\
\hline Largest employers (ABS & 1. Accommodation $(8 \%)$ & 1. Mushroom and vegetable growing & 1. School education $(7 \%)$ \\
\hline 2006) & 2. School education $(5 \%)$ & $\begin{array}{l}(13 \%) \\
\text { 2. School education }(4 \%) \text {. }\end{array}$ & $\begin{array}{l}\text { 2. Cafes, restaurants, and food services } \\
(4 \%) \text {. }\end{array}$ \\
\hline $\begin{array}{l}\text { Rate of home ownership } \\
\text { (Australian average }=0.3 \text { ) }\end{array}$ & 0.5 of occupied homes & 0.4 & 0.3 \\
\hline Other information & & & $\begin{array}{l}\text { One of Australia's } 15 \text { most rapidly } \\
\text { growing coastal cities (Daley and } \\
\text { Lancy 2011). }\end{array}$ \\
\hline
\end{tabular}

ecological vulnerability to climate change is dependent on exposure, sensitivity, ecological vulnerability, resource dependence, and adaptive capacity.

We modify the codependency framework of Marshall et al. (2013) by linking ecological vulnerability to the socioeconomic subsystem. We included the integrated species exposure as a separate component in the socioeconomic subsystem to avoid confusion between the sensitivity of marine species to climate change (biological sensitivity) and the exposure of commercially or recreationally fished species resulting from their management and use, which are not necessarily correlated. Biological sensitivity is based on species-specific biology such as fecundity, temperature range, and ability to move to track preferred environmental parameters (Pecl et al. 2014). The social and economic importance of some species to humans is in this way emphasized and kept separate from the direct biological effects of climate change. If the management of these species is not carefully undertaken there will be an overall impact on ecological vulnerability and through this, there may be potential impact on the socioeconomic vulnerability of the community (Fig. 2). Our definition of ecological vulnerability therefore includes a biological as well as management exposure component.

\section{Data collection}

General demographic and socioeconomic information for communities were collected using publicly available census data from the Australian Bureau of Statistics (http://www.abs.gov.au). Expert opinion and consultation with community members were used to identify location-specific climate and nonclimate pressures impacting marine sectors and the general community (Table 2).

Consultation with community members was in the form of semistructured interviews. Such surveys are known to be effective instruments to consider the scope of existing issues (Kalaugher et al. 2013; Appendix 1). Interview respondents (total $n=83$, comprising Helens: $n=35$; Bowen: $n=23$, Geraldton: $n=25$ ) were contacted by members of the organization OceanWatch
Fig. 2. Framework for the calculation of socioeconomic vulnerability (and adaptive capacity) undertaken for each case study community, modified from Marshall et al. (2013).

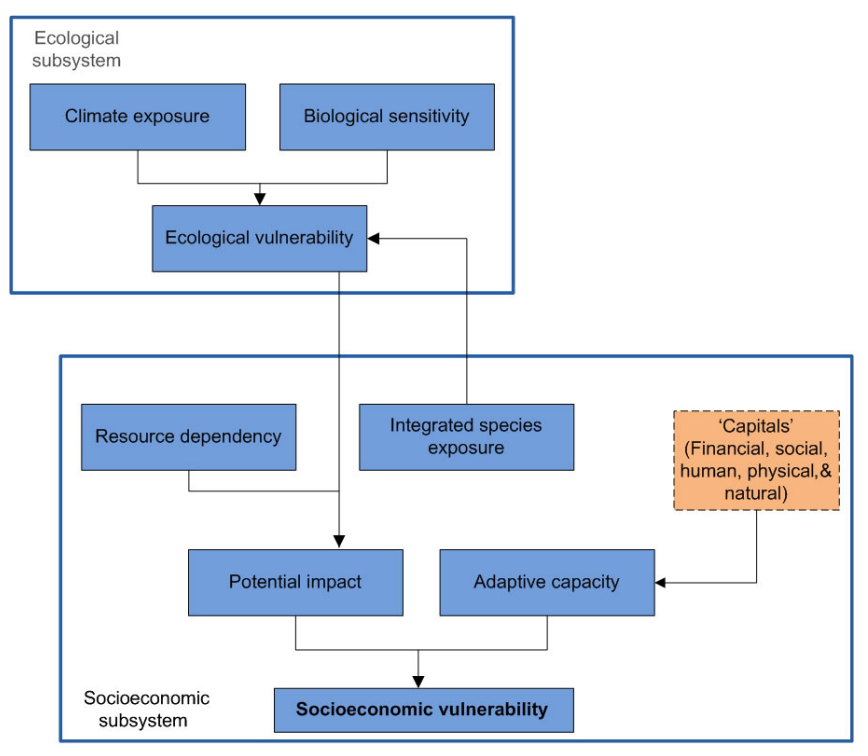

(http://www.oceanwatch.org.au/) who have strong linkages with the fishing industry and coastal communities around Australia. A small number of individuals were attracted through snowball sampling (Goodman 1961) and interest was also garnered through a media release, radio interview, and an information sheet that was publicly available prior to the survey. Interview participants were from a variety of industries and backgrounds including commercial and recreational fishing, aquaculture, marine tourism, accommodation, retail, restaurant, education, local councils, boat maintenance, and marine safety. 
Table 2. Perceptions of climate and main nonclimate changes in the case study communities, as identified by expert opinion and consultation with local community members. Case study examples of changes and impacts are provided.

\begin{tabular}{l}
\hline \hline Climate-induced changes \\
Temperature: warming of coastal waters \\
(incl. heatwaves) \\
Example: Marine heat waves off Geraldton cause higher stress levels in aquaculture species that usually reside in cooler temperate waters. As a result, \\
there may be a shift to species that can reside in warmer waters, such as cobia (Rachycentron canadum) and Spanish mackerel (Scomberomorus \\
commerson). The extreme heat wave of 2011 was observed to cause fish kills and coral bleaching at the Abrolhos Islands. This could affect tourism to \\
the area and potentially impact commercial and recreational fisheries if a regular occurrence. The heat wave also caused a very low recruitment of \\
scallops at the Abrolhos as well as mortality of adults resulting in the fishery being shut from 2012 to the present.
\end{tabular}

Currents: alteration to extent or strength of predominant current

$$
\sqrt{ }
$$

(Increasing strength and extent of East Australian Current)

\section{$\sqrt{ }$}

(Declining strength of the Leeuwin Current predicted in longer term, however, there has been an increase over last two decades)

Example: Changes to ocean temperatures and currents off St Helens cause range expansions/contractions that have positive and negative implications for commercial, recreational, and charter fishing. For instance, the creation of urchin barrens by Centrostephanus rodgersii has negative effects on the commercial rock lobster (Jasus edwardsii) fishery because urchins have removed rock lobster habitat. In contrast, King George whiting (Silagnoides punctatus) and tuna (Thunnus spp.) species are popular with recreational fishers and their presence in the area will benefit recreational and charter fisheries.

Rainfall: increased intensity (causing floods) $\sqrt{ }$ $\times$ $\sqrt{ }$

Example: Rainfall events in St Helens often cause floods. Flooding can temporarily cease oyster harvest because of the potential for high bacterial loads in the reduced salinity waters. This has negative effects for the economic viability of aquaculture businesses, associated transport companies, restaurants, etc., and puts pressure on the domestic market.

Storms (wind) $\times$

$\sqrt{ }$

(Altered location and timing of

storms)
Example: Altered frequency and location of events)

(Increasing strength of East Australian and Hiri Currents) impacts on rock lobster puerulus (larvae) settlement over recent seven years (2006/07 to 2012/13). If westerly winds are not strong at the right time of year, puerulus will not be assisted back to the coast from the Indian Ocean and reduced settlement is more likely. These low settlements negatively affect the commercial fishery through reduced abundance of legal-size lobsters three to four years later and require tighter management regulations with the current catches at about $50 \%$ of the long-term average.

Ocean acidification: increasing acidity $\sqrt{ }$ $\sqrt{ }$ $\sqrt{ }$

Example: At present, little is known about the specific effects of ocean acidification on species in these three locations. Likely impacts are the reduced survivability of species with calcified structures such as oysters, mussels, and clams, as well as impacts on fish homing and predator avoidance.
Main nonclimate changes
St Helens, Tasmania
Geraldton, Western Australia $\sqrt{ }$
$\sqrt{ }$
a
Bowen, Queensland
Variability in tourism

Example: St Helens - Increasing tourism because of good recreational fishing opportunities and beach living.
Geraldton - Decreasing tourism because of inadequate marketing of tourist attractions and lack of accommodation due to occupancy by nonlocal mine/heavy industry workers.

Bowen - Decreasing tourism because of perception that recent cyclones have damaged reefs and infrastructure and a lack of accommodation due to occupancy by nonlocal mine/heavy industry workers.

Availability of (nonlocal) alternative $\sqrt{ }$ $\times$ $\sqrt{ }$

Example: Availability of lucrative employment opportunities elsewhere has caused a decline in the population of working age (25-54 yrs) residents in St Helens and Bowen.

Declining employment in commercial fishing $\sqrt{ }$ $\sqrt{ }$ Example: Declining employment in commercial fishing has occurred because of less family transfer of quota (all locations) the rationalization of the fleet after the implementation of quota management (St Helens and Geraldton), declining access to port through siltation (St Helens), declining target species abundance (e.g., scallops in St Helens and Geraldton), availability of alternative local (Geraldton) and nonlocal (all locations) employment and fisheries management (i.e., the implementation of no fishing Green zones off Bowen).

Declining employment in aquaculture $x$ $\sqrt{ }$ $x$ Example: Insufficient funding to support fledgling aquaculture businesses, inadequate product marketing, and slow shift to more appropriate species for the changing conditions. 


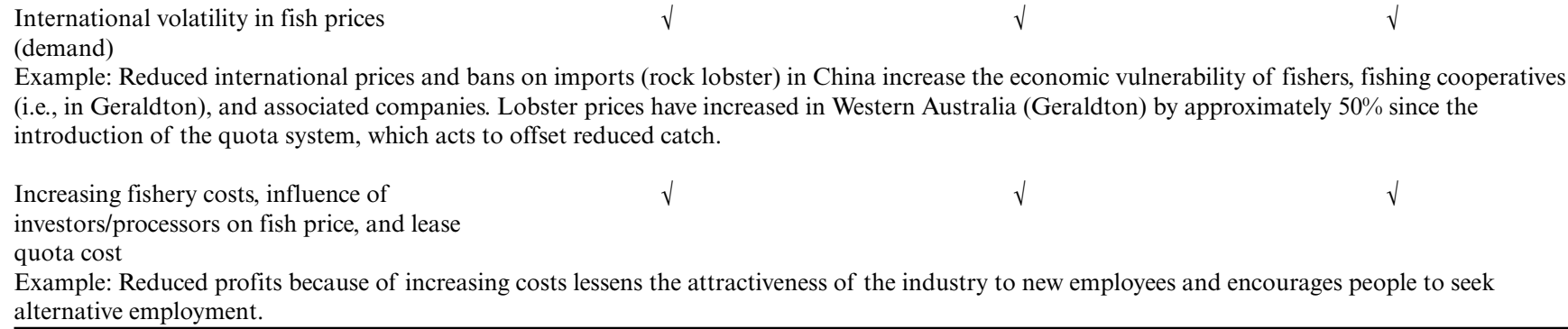

The number of interview respondents was deemed sufficient to provide insights into each community because within each community we were no longer obtaining novel data with additional interviews and were confident that the data recorded was sufficiently robust to draw inferences about the relationship between adaptive capacity and vulnerability. The semistructured survey format reduced potential response bias and assisted in the avoidance of anchoring to the issue of climate change, tactical survey responses, and adverse reactions to participation in a climate change study because attitudes toward climate change in Australia have developed strongly along partisan and ideological divides (see The Climate Institute 2013). Anchoring refers to a specific focus on a topic, such as beliefs regarding climate change, to make subsequent judgements. The semistructured format helped to ensure that all necessary topics were covered and reduced the impact of anchoring on judgements or the use of tactical responses that may be directed at limiting changes in future management.

Interview duration was approximately 60 minutes and focused on the nature of respondents' employment and/or business, how these and the community might be impacted by changes in the marine environment, as well as other socioeconomic changes. The specific impacts of climate and nonclimate pressures were identified to determine potential flow-on effects of change on the marine sectors and other parts of the community. For these analyses, nonclimate drivers were limited to those confirmed to be significant by many respondents. Participants were asked to identify future opportunities to deal with change and potential adaptations that could improve community outcomes. These details provided information on the vulnerability of each participant to change, whether and how the impacts of change permeated throughout the community, and partially indicated their willingness and ability to adapt. For instance, ability to adapt was relevant to respondents who might have acknowledged that climate change has led to changing abundance of local commercial fish species but that they did not have skills to target the new species or seek alternative employment. Indicators of willingness to adapt were where, for example, respondents indicated that they were not willing to find nonfishing employment despite evidence of target species range shifting away from the local area or increasing costs because fishing was their passion and/or identity .

\section{Exposure, sensitivity, and ecological vulnerability}

Estimates of climate exposure and biological sensitivity were used as input variables to determine the social-ecological vulnerability of the coastal communities. The estimated levels of climate exposure were based on projected changes in ocean temperatures (identified using sea surface temperatures, SST), ocean acidification, rainfall, and storms and cyclones in the local area (Table 3). Climate drivers contributing to climate exposure were weighted for each case study. The weighting allocates a higher climate exposure to communities with large expected climate driven changes and a lower climate exposure score for communities with low-moderate expected climate driven changes. Weights were assigned based on reported changes to date (SST, acidification, storms, and cyclones) and future expectations (rainfall; Table 3). They were then summed and averaged to produce the climate exposure metric for each community.

Table 3. Metrics used in the calculation of the climate exposure (CE) for each state using historical and projected climate data. Acidification and storms and cyclone metrics calculated using expert opinion of the authors (physical oceanography expertise) where $2=$ worst impact, $1=$ medium impact, $0=$ low impact.

\begin{tabular}{lccc}
\hline \hline Metric/species score & $\begin{array}{c}\text { Queensland } \\
\text { (Case } \\
\text { study: } \\
\text { Bowen) }\end{array}$ & $\begin{array}{c}\text { Tasmania } \\
\text { (Case } \\
\text { study: St } \\
\text { Helens) }\end{array}$ & $\begin{array}{c}\text { Western } \\
\text { Australia } \\
\text { (Case study: } \\
\text { Geraldton) }\end{array}$ \\
\hline $\begin{array}{l}\text { Sea Surface Temperature } \\
\text { change (SST) } \\
{ }^{\circ} \mathrm{C} \text { warming }\end{array}$ & $\begin{array}{c}1.3 \\
\text { (ave }=26.7)\end{array}$ & $\begin{array}{c}1.7 \\
\text { (ave }=13.8)\end{array}$ & $\begin{array}{c}1.5 \\
\text { (ave }=21.4)\end{array}$ \\
$\begin{array}{l}\text { Acidification } \\
\text { (Ac) }\end{array}$ & 2 & 1 & 1 \\
$\begin{array}{l}\text { Rainfall } \\
\text { (R) projected \% reduction }\end{array}$ & -2.4 & -1.4 & -4.1 \\
$\begin{array}{l}\text { for 2030 } \\
\text { Storms \& cyclones } \\
\text { (Cy) }\end{array}$ & 2 & 0 & 2 \\
\hline
\end{tabular}

${ }^{\dagger}$ Degrees higher in 2009 compared to an average value for the period 1880-2009 for that state, based on the Hadley Centre Sea Surface Temperature dataset.

${ }^{\ddagger}$ Based on CSIRO acidification modeling (significant change $=2$, some change $=1$, no change $=0$ ).

${ }^{\S}$ Projected percent change relative to 1990 state-wide annual average rainfall, best-estimate outcome in a no-mitigation case from CSIRO (2008).

'Based on average increase in projected occurrences from Bureau of Meteorology web site data (greater $=2$, some change $=1$, no change $=$ $0)$.

Biological sensitivity data were taken from Pecl et al. (2014), and Caputi et al. (2014a), and Welch et al. (2014) which followed a similar format. These studies screened key wild capture fishery and aquaculture species to indicate the risks they may face because 
Table 4. Metrics used in the calculation of the biological sensitivity (BS) and the integrated species exposure (ISE $=\mathrm{Eb}+\mathrm{Sb}+\mathrm{Gb})$ for individual species. Economic, social, and governance categories were taken from IPCC (2007) report. NPA = National Partnership Agreements, TEP $=$ Threatened, Endangered and Protected species, EPBC $=$ Environment Protection and Biodiversity Conservation.

\begin{tabular}{|c|c|c|c|c|c|}
\hline \multicolumn{6}{|l|}{ Metric/species score } \\
\hline$\overline{\text { Biological sensitivity (BS) }})^{\dagger}$ & 1 - Low & 1.5 - Medium-Low & 2 - Medium & 2.5 - Medium-High & 3 - High \\
\hline Economic (Eb) & $\begin{array}{l}0 \text { - No economic } \\
\text { value }\end{array}$ & $1-<\$ 5 \mathrm{M}$ & $2-\$ 5-\$ 20 M$ & $3->\$ 20 \mathrm{M}$ & \\
\hline Social (Sb) & $\begin{array}{l}0 \text { - No } \\
\text { recreational/ } \\
\text { tourism interest }\end{array}$ & $\begin{array}{l}1 \text { - Recreationally } \\
\text { important (locally) }\end{array}$ & $\begin{array}{l}2 \text { - Recreationally } \\
\text { important (locally } \\
\text { and tourists) }\end{array}$ & & \\
\hline Governance (Gb) & $\begin{array}{l}0 \text { - No governance } \\
\text { issues }\end{array}$ & $\begin{array}{l}1 \text { - International } \\
\text { agreements (NPAs) - } \\
\text { nonbinding }\end{array}$ & $\begin{array}{l}2 \text { - TEP under } \\
\text { EPBC Act }\end{array}$ & & \\
\hline
\end{tabular}

${ }^{\dagger}$ (modified from Pecl et al. 2014).

of climate change (Pecl et al. 2014). This screening reviewed the existing literature and assessed the potential impact of physical changes (e.g., rainfall, wind, temperature) on the abundance and, distribution of species populations and the timing of life cycle events. Pecl et al. (2014) produced a sensitivity score (low, 1 to high, 3) for each species for potential impacts to each of "abundance," "distribution," and "timing of life cycle events," and then summed these to achieve an overall sensitivity to climate change score ranging from low (3) to high (9) sensitivity. To ensure consistency in the metric, the sensitivity scores were rescaled to values between 1 (Low) and 3 (High).

Integrated species exposure was estimated (Table 4) using economic, social, and governance scores for commercial and recreational species (IPCC 2007). Biological sensitivity, and the social, economic, and governance scores were summed and averaged according to the number of species in the screening studies of Pecl et al. (2014) for St Helens, Caputi et al. (2014a) for Geraldton, and Welch et al. (2014) for Bowen to provide a comparable final integrated species exposure score for each community (Table 5). Ecological vulnerability is the sum of climate exposure, average biological sensitivity, and integrated species exposure for each location (Table 5).

\section{Capitals and resource dependence}

Determinants of adaptive capacity are often difficult to measure or assess without extensive and costly surveying of individuals and, consequently, indicators of adaptive capacity are often used (Vincent 2007). To overcome the temporal and financial challenges of collecting longitudinal data from multiple locations, we use indicators of adaptive capacity based on existing secondary datasets to estimate the five sustainable livelihoods analysis capitals and to calculate adaptive capacity (Table 6). Although the use of longitudinal information from the case study communities may have increased the level of detail and quality of the results, without the use of secondary datasets the study could not have been undertaken. A related project using longitudinal data is currently being undertaken in Geraldton (M. Tull, H. Gray, and S. Metcalf, unpublished manuscript).

Many variables have been suggested as indicators of adaptive capacity but there has been little testing of their predictive power to explain observed vulnerability (Stenekes et al. 2012). The indicators selected for use in this study were chosen on the basis of their inclusion in other studies, data availability and regional coverage, expert opinion, and local qualitative information. The taped interviews with community survey respondents helped researchers select relevant indicators but there was no formal process by which respondents were asked to contribute to indicator selection. For example, respondents mentioned that the high number of seasonal residents in their coastal community impacted their ability to form cohesive volunteer community services such as surf lifesavers. A volunteering indicator was therefore included to measure social capital. The indicator set was limited to a small number of variables but additional variables can be easily included as they become available at a later stage.

Specific indicator data was collected prior to and during case study visits using the literature, census data, participant reports and expert opinion inherent in the project team. Indicators for natural capital generally tend to be either biophysical or monetary. However, to ensure access to information for all communities we have used the proportion of employment in agriculture, fisheries and forestry (census grouping) as a proxy for capital in the natural ecosystem (sensu Regional Australia Institute 2013) where higher employment denotes past use of the ecosystem and hence could explain poorer current condition. To allow access to information regarding private physical capital at the local community scale we have used the proportion of business owner/managers and houses owned outright. These indicators assume that owners of businesses and houses contribute equipment and other assets that, if necessary, can be used to assist the broader community in responding to change.

For each indicator, the Australian average, an estimate for the community $(x)$, and the maximum state value were identified. Indicators were then scored using three inequalities:

if $x<$ Australian average, then score $=0$;

if Australian average $<x<$ maximum state value, then score $=1$;

if $x>$ maximum state value, then score $=2$

where 0 was considered to be "good" and 2 was "poor." The nature of some indicators determines that their scores had to be inverted. For example, communities with employment and education levels that were higher than the Australian average were scored as 0 , while those with very low levels as 2 . 
Table 5. Variables, definitions, and equations used to calculate socioeconomic vulnerability of the case study communities. Species used in BS and ISE calculations are from Caputi et al. (2014a), Pecl et al. (2014), and Welsh et al. (2014).

\begin{tabular}{lll}
\hline \hline Variable & New definitions & Equation \\
\hline Climate exposure (CE) & Sea surface temperature (SST) & $C E=\operatorname{sum}\left(a^{\text {local }} \mathrm{SST}, b^{\text {local }} \mathrm{Ac}, c^{\text {local }} \mathrm{R}, d^{\text {local }} \mathrm{Cy}\right)$ \\
& Acidification (Ac) & \\
& Rainfall (R) & \\
& Storms \& cyclones (Cy) & \\
& $a \ldots d^{\text {local }}=$ localized weighting assigned to each climate & \\
& driver & ISE $=\operatorname{sum}(n \mathrm{~Eb}+n \mathrm{Sb}+n \mathrm{~Gb}) / n_{B S}$ \\
Integrated species exposure (ISE) & Economic importance by species (Eb) & \\
& Social importance by species (Sb) & \\
& Governance regulation required by species $(\mathrm{Gb})$ (sensu & \\
& IPCC 2007) & \\
& Number of species considered for biological sensitivity in & \\
Ecological vulnerability (EV) & the region $\left(n_{B S}\right)$ & $E V=C E+\left(\operatorname{sum}\left(B S_{n}\right) / n_{B S}\right)+I S E$ \\
Potential impact (PI) & Biological sensitivity (BS) by species & $P I=E V+R D$ \\
Adaptive capacity (AC) & Resource dependence (RD) & $A C=\operatorname{sum}($ natural $(n)$, physical $(p)$, social $(s)$, \\
& See Introduction for description of each capital & human $(h)$, financial $(f)$ capital $)$ \\
Socioeconomic vulnerability (SEV) & & $S E V=P I+A C$ \\
\hline
\end{tabular}

Table 6. Indicators and scoring used to calculate the value of the five capital assets and marine resource dependence. Each indicator has an initial maximum possible value of 2 and a minimum of 0 where indicator value $<$ Australian average, then $=0$ (good), Australian average $<$ indicator value $>$ max state value, then $=1$ (moderate), indicator value $>\max$ state value, then $=2$ (poor). To compare the scores across all capitals, the values were then adjusted to be out of 10 , i.e., if $10.00<\operatorname{sum}$ (indicators) $\times$ adjustment factor $>6.67$, low (i.e., poor), if $6.67<$ sum(indicators) $\times$ adjustment factor $>3.34$, medium, and if $3.34<$ sum(indicators) $\times$ adjustment factor $>0$, high (i.e., good).

\begin{tabular}{|c|c|c|c|}
\hline$\overline{\text { Category }}$ & Indicators & $\begin{array}{l}\text { Indicators for which scores are } \\
\text { inversed }\end{array}$ & Adjustment factor \\
\hline $\begin{array}{l}\text { Marine resource } \\
\text { dependence (RD) }\end{array}$ & $\begin{array}{l}\text { 1) Employment in fishing (proportion; level } 3 \text { census category) } \\
\text { 2) Employment in aquaculture (proportion; level } 3 \text { census } \\
\text { category) } \\
\text { 3) Employment in accommodation and restaurants (proportion) }{ }^{\dagger}\end{array}$ & & 1.67 \\
\hline $\begin{array}{l}\text { Natural capital } \\
\text { (n) }\end{array}$ & $\begin{array}{l}\text { 1) Employment agriculture/forestry/fishing and mining } \\
\text { (proportion; level } 1 \text { census categories) }\end{array}$ & & 5 \\
\hline $\begin{array}{l}\text { Human capital } \\
\text { (h) }\end{array}$ & $\begin{array}{l}\text { 1) Unemployment rate } \\
\text { 2) Education levels } \\
\text { 3) Full-time versus part-time employment } \\
\text { 4) Females employed (proportion) } \\
\text { 5) People requiring social assistance (proportion) } \\
\text { 6) People whose place of residence is different to one year ago } \\
\text { (proportion) }\end{array}$ & $\begin{array}{l}\text { Employment } \\
\text { Education levels, } \\
\text { Full:part-time employment } \\
\text { Prop. of females employed }\end{array}$ & 0.83 \\
\hline $\begin{array}{l}\text { Financial capital } \\
\text { (f) }\end{array}$ & $\begin{array}{l}\text { 1) Average weekly household income } \\
\text { 2) Ratio of male to female total earnings } \\
\text { 3) Median mortgage repayments } \\
\text { 4) Age dependency ratio }\end{array}$ & $\begin{array}{l}\text { Average weekly household } \\
\text { income }\end{array}$ & 1.25 \\
\hline $\begin{array}{l}\text { Social capital } \\
\text { (s) }\end{array}$ & $\begin{array}{l}\text { 1) Proportions of one parent families with children }<15 \text { years } \\
\text { 2) People who volunteer (proportion) } \\
\text { 3) Unoccupied dwellings (proportion) } \\
\text { 4) Population change } \\
\text { 5) People per household and the index of disadvantage }\end{array}$ & $\begin{array}{l}\text { Volunteering activity, } \\
\text { change in population size }\end{array}$ & 1 \\
\hline $\begin{array}{l}\text { Physical capital } \\
\text { (p) }\end{array}$ & $\begin{array}{l}\text { 1) Proportions of houses owned outright } \\
\text { 2) Business owner/managers (proportion) } \\
\text { 3) Self-employment (proportion) }\end{array}$ & All & 1.67 \\
\hline
\end{tabular}

\footnotetext{
${ }^{\dagger}$ Assumes 40\% attributable to marine environment (Australian Institute of Marine Science 2012).
} 
Table 7. Case study results contributing to the calculation of adaptive capacity and socioeconomic vulnerability to marine climate change impacting coastal livelihoods. Adaptive capacity and socioeconomic vulnerability scores have been rounded to the nearest whole number.

\begin{tabular}{|c|c|c|c|c|}
\hline Metric or variable & $\begin{array}{l}\text { St Helens, } \\
\text { Tasmania }\end{array}$ & Bowen, Queensland & $\begin{array}{c}\text { Geraldton, Western } \\
\text { Australia }\end{array}$ & Interpretation \\
\hline Resource Dependence & 10.00 & 10.00 & 8.33 & $\begin{array}{l}10 \text { - Very dependent on resources for } \\
\text { employment } \\
0 \text { - Independent of resources for } \\
\text { employment }\end{array}$ \\
\hline Natural capital & 10.00 & 10.00 & 0.00 & $\begin{array}{l}10 \text { - Low (poor) } \\
0 \text { - High }\end{array}$ \\
\hline Human capital & 8.33 & 4.99 & 4.99 & $\begin{array}{l}10 \text { - Low (poor) } \\
0 \text { - High }\end{array}$ \\
\hline Financial capital & 5.00 & 3.75 & 5.00 & $\begin{array}{l}10 \text { - Low (poor) } \\
0 \text { - High }\end{array}$ \\
\hline Social capital & 3.00 & 4.00 & 2.00 & $\begin{array}{l}10 \text { - Low (poor) } \\
0 \text { - High }\end{array}$ \\
\hline Physical capital & 5.00 & 6.67 & 10.00 & $\begin{array}{l}10 \text { - Low (poor) } \\
0 \text { - High }\end{array}$ \\
\hline Adaptive capacity & 31 & 29 & 22 & $\begin{array}{l}0 \text { - High (good) capacity to adapt } \\
50 \text { - Low (very poor) capacity to } \\
\text { adapt }\end{array}$ \\
\hline Biological sensitivity & 2.13 & 2.62 & 2.41 & $\begin{array}{l}\text { Larger score - more sensitive to } \\
\text { biological effects of climate change }\end{array}$ \\
\hline Integrated species exposure & 1.57 & 1.61 & 2.18 & $\begin{array}{l}\text { Larger score -greater social, } \\
\text { economic and management } \\
\text { importance of locally fished species }\end{array}$ \\
\hline Climate exposure & 4.13 & 7.73 & 8.58 & $\begin{array}{l}\text { Larger score - greater potential for } \\
\text { marine climate change impacts to } \\
\text { occur }\end{array}$ \\
\hline Ecological vulnerability & 7.83 & 11.95 & 13.17 & $\begin{array}{l}\text { Larger score - greater exposure and } \\
\text { sensitivity of fished species }\end{array}$ \\
\hline Potential impact & 17.83 & 21.95 & 21.50 & $\begin{array}{l}\text { Larger score - greater potential for } \\
\text { impacts on fished species because of } \\
\text { marine climate change }\end{array}$ \\
\hline Socioeconomic vulnerability & 49 & 51 & 44 & $\begin{array}{l}0 \text { - Coastal community has low } \\
\text { vulnerability to the effects of marine } \\
\text { climate change } \\
79 \text { - Coastal community has very } \\
\text { high vulnerability to the effects of } \\
\text { marine climate change }\end{array}$ \\
\hline
\end{tabular}

Even though marine resource dependence is, in reality, a broader concept than simply employment, the indicators used here include the proportion of people working in marine industries such as fishing and aquaculture and the proportion of people working in the broader Census category "Agriculture, forestry and fishing" because this group cannot be disaggregated into fishing alone (Table 6). The proportion of people working in accommodation and restaurants related to the marine environment also contributed to marine sector dependence. It was assumed that $40 \%$ of the total employment in this sector was attributable to the marine environment through tourism and seafood sales (sensu AIMS 2012). The variable value was calculated using the same methods as that applied to the other indicators.

Resource dependence and capital values were calculated out of 10 , which allowed comparison between the scores. Because a different number of indicators were used to construct each metric, we used an adjustment factor to allow this comparison (Table 6). For example, resource dependence was calculated using three indicators with maximum values of 2 per indicator (i.e., highest possible score $=6$ ). A town with a preliminary resource dependence score of 4 was thus adjusted to 6.67 (i.e., $10 / 6=1.67$ and $1.67 \times 4=6.67$ ).

\section{Socioeconomic vulnerability and adaptive capacity}

The five sustainable livelihoods analysis capitals were summed to calculate the adaptive capacity of each community. The adaptive capacities, along with ecological vulnerability and resource dependence were then used to calculate social-ecological vulnerability to marine climate change according to the values and equations in Tables 5 and 7.

A qualitative comparison of the socioeconomic vulnerability and adaptive capacity of the three case study communities was undertaken. In this qualitative assessment, the capital scores are discussed with reference to reducing vulnerability and increasing adaptive capacity, however, substitution between the capitals is not a specific focus because this would require a more detailed and contextualised analysis. It should be noted that scores for 
resource dependence and the five capitals have an inverse relationship. See Table 7 for an interpretation of scores.

\section{Identification of adaptation strategies and trade-offs}

Possible actions to enable adaptation were identified in community interviews and through literature review following the interviews prior to the calculation of socioeconomic vulnerability and adaptive capacity. Following calculation of metrics, these actions were identified as potential adaptation strategies and reported in the Results if they were found to have the potential to reduce a negative impact or increase adaptive capacity. More specifically, an adaptation strategy could, for instance, improve/ increase the viability or abundance of an asset or capital (e.g., target species, employment, population, tourism, aquaculture). Unique potential adaptation strategies were identified for each case study location in addition to more generic adaptation strategies that were identified for all communities (Tables 8-9). Actions that were suggested during interviews and literature review that were not able to reduce vulnerability or increase adaptive capacity in the three case study locations have not been reported because they were not identified as potential adaptation strategies for these communities.

To allow for improved sustainable livelihoods, the implementation of adaptations that improve those capitals with lower adaptive capacity scores was a priority in the analysis. However, no single adaptation is likely to improve all capitals simultaneously, and thus a trade-off with some neutral and negative outcomes must often be considered to maximize the overall benefits (Farrington et al. 1999).

\section{Potential barriers to successful implementation}

The capacity of the coastal community to implement proposed adaptation strategies was qualitatively assessed on the basis of their adaptive capacity. The sustainable livelihoods analysis capital scores help to identify where potential constraints to improved livelihoods may exist. The assessment of potential implementation success remained qualitative in this study, despite the semiquantitative nature of the vulnerability and adaptive capacity results because it also depends on multiple external factors such as knowledge and a willingness to adapt (Frick et al. 2004) and additional climate or nonclimate changes that may alter the adaptations (increase or decrease scope, or change actions) that are necessary. In addition, the selection of indicators for the capital scores was limited by the availability of easily accessible information, i.e., census data, and barriers to successful implementation may arise from numerous other areas, including governance constraints.

Successful implementation of many of the identified adaptation options requires communities to have access to a number of basic attributes such as funds for expansion/start-up of businesses (financial capital). Basic attributes necessary to enable proposed adaptation strategies in the case study communities have been addressed with reference to adaptive capacity and the capacity of each community to successfully implement adaptations.

\section{RESULTS}

Case study communities, climate and nonclimate drivers Each community differed markedly in terms of fisheries production and value, industry composition, and community demographics, including population size (Table 1; for additional detail see van Putten et al. 2014). To varying degrees, each community was also subject to climate and nonclimate drivers, such as warming coastal waters, changing currents, and variability in local tourism (Table 2).

\section{Social-ecological vulnerability and adaptive capacity}

Resource dependence was very high in both St Helens and Bowen (high score) whereas natural capital, as measured by the proportion of people employed in agriculture, fishing, and forestry, was very low (Table 7). Geraldton had moderately high resource dependence and high natural and social capitals. All other capital scores were relatively similar between case study towns excluding physical capital where Geraldton scored very poorly and St Helens scored moderately well. These results were highly influential in determining the adaptive capacity of each town, with Geraldton having the highest adaptive capacity of the three case study towns followed by Bowen and St Helens, respectively.

St Helens was found to have the poorest score for natural and human capitals. This community also had the smallest population size and adaptive capacity but had greater physical capital (score closer to zero) than both Geraldton and Bowen. Despite its moderate adaptive capacity in comparison to St Helens, Bowen was found to have the highest social-ecological vulnerability (Bowen: 51, St Helens: 49, Geraldton: 44) from the three case study towns. Bowen's high social-ecological vulnerability stemmed from its high biological sensitivity and moderate integrated species and climate exposure scores. St Helens, in comparison, had the lowest biological sensitivity, integrated species, and climate exposure scores of the three case study towns.

Based on ecological vulnerability alone, Geraldton had the greatest potential impact from climate change, specifically, projected change in rainfall and the social and economic importance of the target species assessed (e.g., rock lobster, abalone spp.). However, its social-ecological vulnerability was buoyed by the relatively moderate resource dependence and strong social and natural capital scores.

\section{Adaptation strategies, potential barriers, and trade-offs}

Adaptation strategies to diversify, re-establish, and maintain local markets for fish were commonly identified for all three case study communities (Table 8). Similarly, increasing the output and function of aquaculture and increasing marketing and tourist numbers were identified in all locations. These potential adaptations were reported because they provide sources of income and employment, an alternative source of fish products and a more diverse economic base, all of which would likely improve human, financial, social, and physical capital in each coastal community.

A number of unique potential adaptations were found to exist for each community (Table 9). For example, a unique adaptation in St Helens was to increase capacity for factory-based urchinprocessing of the invasive urchin species, C. rodgersii. This adaptation could improve financial and human capitals and also provide additional employment opportunities. However, this adaptation would also increase resource dependence in St Helens, which carries an inherent risk for the community with the additional employment generated by an industry exposed to 
Table 8. Adaptations, reasoning, and expected trade-offs identified for all case study communities.

\begin{tabular}{|c|c|}
\hline Sector & Adaptation \\
\hline $\begin{array}{l}\text { Commercial } \\
\text { fishing }\end{array}$ & $\begin{array}{l}\text { Diversify, re-establish and maintain a } \\
\text { local and domestic market for } \\
\text { commercially captured fish. }\end{array}$ \\
\hline $\begin{array}{l}\text { Commercial } \\
\text { fishing }\end{array}$ & $\begin{array}{l}\text { Develop courses that inform fishers } \\
\text { about: } \\
\text { - potential financial implications of } \\
\text { species range shifts } \\
\text { - implications of changing species } \\
\text { abundance on quota } \\
\text { - succession planning. }\end{array}$ \\
\hline $\begin{array}{l}\text { Commercial } \\
\text { fishing }\end{array}$ & $\begin{array}{l}\text { Monitoring of prerecruit abundance } \\
\text { as an early warning to changing } \\
\text { abundance of key stocks. }\end{array}$ \\
\hline
\end{tabular}

Commercial Encourage more transparency in fishing pricing systems set by processing industry to allow greater understanding of value-adding over the supply chain and provide fishers with improved bargaining power.

Commercial During boom times in other sectors -

fishing labor shortages could be addressed by incentives to retain skill base and labor. Potential use of temporary migration visas.

Commercial Balanced representation on

fishing comanagement committees and industry bodies through better rotation times, term limitations, and incentives to participate.

Aquaculture Increase aquaculture output and function.

Aquaculture Support local aquaculture by increasing collaboration with research institutions to enhance diversification to new species in anticipation of marine climate pressures.

Aquaculture Encourage investigation of closed onland systems to ensure development of aquaculture into the future.

Recreational Improve recreational catch monitoring Benefits: Social and human fishing and policing of rules to reduce conflict Disadvantages: Natural between sectors and establish catch share arrangements between commercial and recreational fishers.

Recreational Keep infrastructure provisions in step fishing with growth in recreational fishing.

Recreational Flexible and adaptive rule

fishing development for unmanaged species.

(within community)
Benefits: Human and physical
Disadvantages: Financial (setup funds required) and natural

Benefits: Financial and huma

Disadvantages: Natural and

between re-establishing

domestic market and use in

Benefits: Human

Disadvantages: Natural

Benefits: Financial

Disadvantages: Natural

Benefits: Social

Benefits: Financial and human Disadvantages: Financial (setup funds required) and natural (potential pressure on local environment).

Benefits: Social, human, and financial

Disadvantages: Natural

Benefits: Physical

Disadvantages: Natural

Benefits: Financial

Disadvantages: Natural export markets).

Trade-offs between capitals Reasoning

Reliance on single export markets is risky. Can mitigate effects of falling export markets and increasing costs by providing domestic income. Provide locals/businesses and tourists with fresh local fish.

Fishers may wish to learn how to develop investment plans to determine if investing in new opportunities, e.g., larger vessel, purchasing more/selling quota, is worthwhile. Provide information sessions on the value of different retirement options that are available with respect to retaining or selling quota.

An early warning to changing abundance of fish stocks gives industry and managers an ability to adapt fishing practices and avoid overfishing of poor year classes.

Fishers often become price takers because they are increasingly bound to processors/buyers that set fish prices. There is little competition between processors/buyers because of their limited numbers. Improved bargaining power is desirable to support commercial fisheries into the future.

High wages in the mining and oil and gas sectors mean fishers have trouble retaining reliable deckhands and therefore can struggle to maintain catches.

Need for balanced representativeness and membership renewal for industry bodies and comanagement decision committees. Adequate reimbursements and more locally held meetings are required to help overcome issues such as loss of fishing time.

Provides an alternative source of employment for wild capture fishers forced to leave the industry because of climate, quota, and cost issues. Also supports associated industries such as transport/processing, which may provide critical employment opportunities. Provides fish to local, domestic, and international markets.

Close collaboration with research institutions can increase knowledge and reduce the influence of high development costs associated with new aquaculture enterprises through cofunding arrangements.

At-sea aquaculture is constrained by available farming space and limited expansion is possible in the majority of situations. Knowledge of and construction of on-land systems can allow industry expansion to occur.

A more frequent official count of participation and catch estimates is necessary to reduce conflict. Although difficult to estimate, illegal catches should/could be better accounted for and incorporated into catch estimates to improve management.

Provide reasonable access to jetties to avoid "boat ramp rage" with increasing recreational fishing participation. When new (commercial) species appear in local waters management decisions have to be prompt and flexible to avoid a "gold rush" and maintain the fishery into the future. 


\begin{tabular}{llll}
$\begin{array}{l}\text { Marine } \\
\text { tourism }\end{array}$ & $\begin{array}{l}\text { Encourage increased tourism through } \\
\text { improved marketing/promotion. } \\
\text { Develop good information dispersal to } \\
\text { inform public (elsewhere) about access } \\
\text { and local conditions after severe }\end{array}$ & Benefits: Financial and human & $\begin{array}{l}\text { Provides more consistent income to tourism operators and } \\
\text { associated businesses. Access to towns is often affected by } \\
\text { extreme events and needs to be managed quickly to } \\
\text { maintain tourist visitation. Distribution of correct } \\
\text { information on reef state is needed. }\end{array}$ \\
$\begin{array}{l}\text { weather events. } \\
\text { Earine } \\
\text { Encourage opportunities for } \\
\text { community participation in scientific } \\
\text { research. }\end{array}$ & Benefits: Social and human \\
Community & $\begin{array}{l}\text { Maintain local engineering /support } \\
\text { services to maintain contribution to } \\
\text { local employment and economy. }\end{array}$ & $\begin{array}{l}\text { Benefits: Financial, human, } \\
\text { and physical }\end{array}$ & $\begin{array}{l}\text { Local participants in marine sectors feel there are few } \\
\text { avenues available to provide information to science (apart } \\
\text { from RedMap). } \\
\text { Infrastructure and service provision to fishers becomes } \\
\text { increasingly problematic with a declining commercial fishing } \\
\text { sector. Supports local employment and helps maintain } \\
\text { infrastructure. }\end{array}$ \\
\hline
\end{tabular}

marine climate change and therefore vulnerable to climateinduced downturns. In practice, to determine whether the tradeoff between employment opportunities and greater resource dependence is likely to be largely positive, the indirect benefits, such as a reduction in the abundance of $C$. rodgersii, must also be undertaken. C. rodgersii is a barren-forming urchin and a reduction in its abundance would be beneficial for local rock lobster and abalone fisheries through the promotion of algal regrowth.

Synergies and trade-offs between capitals were identified for other adaptation strategies (Tables 8-9). For instance, strategies that increased employment in fisheries and aquaculture would reduce overall community unemployment (improve human capital), help to maintain population (improve/maintain social capital) and improve financial capital while also increasing the resource dependence (reduced natural capital) of the community. The potential vulnerability of the community to the impacts of climate change is therefore a function of all above changes in sustainable livelihoods analysis capitals and ultimately social-ecological vulnerability. Unique adaptations in Geraldton tended to focus on directly improving education and communication, which can improve employment opportunities, fisheries management, and aquaculture. The adaptation of moving to the rock lobster quota system is already in place (2010) and has resulted in a loss of population and community (social capital) from the Abrolhos Islands. However, this adaptation has also improved financial capital through higher catch rates that increase the level of profitability and has allowed a higher level of spawning stock, making the fishery more resilient to environmental perturbations. Other suggested adaptations in Geraldton can improve human and long-term financial capital but also cause a short-term financial cost through the need for start-up funds for research, renewable energy production, and aquaculture expansion. When the costs and benefits are not borne by the same groups, an increased reluctance to adapt may occur.

Barriers to improving livelihoods in the coastal communities arose for a number of reasons including a heavy reliance on a single sector for employment, e.g., high resource dependence. Geraldton was found to be lacking in private physical capital, which may pose a barrier to the implementation of increased aquaculture and renewable energy production. Similarly, the implementation of adaptations such as the provision of infrastructure for recreational fishing, research into aquaculture, and the promotion of tourist destinations may be constrained by relatively low financial capital in St Helens and Geraldton. Bowen possessed relatively low social capital reflecting a high rate of population change, low levels of volunteering, and a large number of unoccupied dwellings. This lack of social capital may constrain the implementation of adaptations such as encouraging participation in scientific research, the communication of weather and condition (i.e., road and rail damage following cyclonic events) reports, and gaining balanced representation on comanagement committees and industry bodies.

\section{DISCUSSION}

To assist coastal communities in coping with climate change, an understanding of adaptive capacity and social-ecological vulnerability can be used to inform the development of adaptation actions and their implementation. Through the characterization of the community, the social-ecological vulnerability can provide a context for the identification of enablers and barriers to adaptation. This process involves the identification and measurement of components contributing to adaptive capacity and vulnerability (Engle 2011) as well as the identification of potential adaptations that augment and diminish adaptive capacity (Adger 2001, Smit and Wandel 2006). Through the identification of enablers and barriers to the implementation of adaptations, planning for synergies and trade-offs can be undertaken. Although work on adaptive capacity and adaptation planning has been increasing in recent years (e.g., Australian Government 2007, COAG 2007, Regional Australia Institute 2013), we find that quantitative assessments of adaptive capacity and ecological vulnerability are useful in identifying and comparing the overall social-ecological vulnerability of coastal communities reliant on the marine resource sector. Furthermore, with receptive decision-makers and institutions, the methods employed in this study could be transferred to other geopolitical scales, e.g., states or countries, and different situations such as noncoastal and urban environments (Ekstrom and Moser 2013). As a result of the process described above, a website that comprises a climate change blueprint designed to provide targeted preliminary information on potential impacts of climate change, community vulnerability, and adaptive capacity to a broad audience has also been produced with the aim of assisting community-led investigations into climate change adaptation (http://coastalclimateblueprint.org.au/). This self-assessment website allows easy access and use by practitioners and the general public alike. 
Table 9. Unique community-based adaptations, reasoning, and trade-offs for the three case study communities.

\begin{tabular}{|c|c|c|c|c|}
\hline Location & Sector & Adaptation & $\begin{array}{l}\text { Trade-offs between } \\
\text { capitals (within } \\
\text { community) }\end{array}$ & Reasoning \\
\hline St Helens & $\begin{array}{l}\text { Commercial } \\
\text { fishing }\end{array}$ & Increase urchin factory production. & $\begin{array}{l}\text { Benefits: Financial and } \\
\text { human } \\
\text { Disadvantages: Natural }\end{array}$ & Provide a source of local employment. \\
\hline St Helens & Processing & Separate processors from investors. & Benefits: Financial & $\begin{array}{l}\text { To provide more transparent and flexible pricing of } \\
\text { fish. }\end{array}$ \\
\hline Bowen & $\begin{array}{l}\text { Commercial } \\
\text { fishing }\end{array}$ & $\begin{array}{l}\text { Closure of cyclone-damaged area } \\
\text { and shift of fishing effort elsewhere. }\end{array}$ & $\begin{array}{l}\text { Benefits: Natural and } \\
\text { financial } \\
\text { Disadvantages: Natural } \\
\text { (trade-off between short- } \\
\text { term and long-term } \\
\text { employment) }\end{array}$ & $\begin{array}{l}\text { To allow stock regeneration on affected reefs and } \\
\text { ensure employment and local fish availability are } \\
\text { maintained. }\end{array}$ \\
\hline Geraldton & All & $\begin{array}{l}\text { Increase research in renewable } \\
\text { energy, aquaculture, and fisheries. } \\
\text { Increase education for commercial } \\
\text { and recreational fisheries } \\
\text { compliance. }\end{array}$ & $\begin{array}{l}\text { Benefits: Human and } \\
\text { financial } \\
\text { Disadvantages: Financial } \\
\text { (set-up funds required) }\end{array}$ & $\begin{array}{l}\text { To allow utilization of likely impacts from climate } \\
\text { change through renewable energy and continue to } \\
\text { increase production of aquaculture and wild caught } \\
\text { species. }\end{array}$ \\
\hline $\begin{array}{l}\text { Geraldton } \\
\text { and } \\
\text { Bowen }\end{array}$ & Community & $\begin{array}{l}\text { Better communication of the } \\
\text { benefits of aquaculture products } \\
\text { and renewable energy. Distribute } \\
\text { public information regarding the } \\
\text { level of impact from local } \\
\text { aquaculture (particularly prawn) } \\
\text { and renewable energy ventures. }\end{array}$ & Benefits: Human & $\begin{array}{l}\text { Aquaculture and renewable energy are often perceived } \\
\text { to damage nearby coastal ecosystems, species, or } \\
\text { visual amenity. This is often not the case and these } \\
\text { negative perceptions may be mediated by improved } \\
\text { communication and public education. }\end{array}$ \\
\hline Geraldton & $\begin{array}{l}\text { Renewable } \\
\text { energy }\end{array}$ & $\begin{array}{l}\text { Increase renewable energy } \\
\text { production and sales. }\end{array}$ & $\begin{array}{l}\text { Benefits: Financial and } \\
\text { human } \\
\text { Disadvantages: Financial } \\
\text { (set-up funds required) }\end{array}$ & $\begin{array}{l}\text { Utilise climate change impacts to provide an } \\
\text { additional source of local employment and produce } \\
\text { cheaper energy. Cheaper energy could encourage } \\
\text { additional industrial investment in the region and } \\
\text { reduce household costs. }\end{array}$ \\
\hline Geraldton & $\begin{array}{l}\text { Commercial } \\
\text { fishing }\end{array}$ & $\begin{array}{l}\text { Maintain rock lobster fishing quota } \\
\text { system. }\end{array}$ & $\begin{array}{l}\text { Benefits: Financial } \\
\text { Disadvantages: Social } \\
\text { (decline in population and } \\
\text { community from Abrolhos } \\
\text { Islands) }\end{array}$ & $\begin{array}{l}\text { After initial loss of fishers following implementation } \\
\text { of quota system, the new system has been found to } \\
\text { allow better catch rates and require fewer fishing days } \\
\text { per year because fishers are now fishing close to the } \\
\text { maximum economic yield (i.e., maximum profits). }\end{array}$ \\
\hline
\end{tabular}

Knowledge of local climate change drivers and current and future impacts is important for adaptation planning to be successful in marine dependent communities. However, regardless of whether exact climate change impacts are known, the basic capacity for a community to implement adaptations depends on the relevant institutional arrangements and the characteristics that the community possesses (O'Brien et al. 2006, Adger et al. 2009, Barnett et al. 2014). For example, a community with a high level of education, adequate financial assets, and social and institutional cohesiveness may adapt to unexpected impacts from climate change because of its relatively high existing adaptive capacity. In comparison, a community with low adaptive capacity may struggle to cope with existing impacts let alone cope with unexpected and new impacts. Knowledge of human, social, financial, natural, and physical capitals can be used to assist adaptation implementation as well as supporting the success of adaptations once implemented. Even though the assessment characterizes community adaptive capacity by means of the SLA capitals, the institutional context has not been considered in any detail. This is an important point for future studies because institutions and associated rules and regulations are often the facilitators of, and barriers to, adaptation. A useful extension to this current research would be to incorporate quantitative measures of institutional and governance barriers or facilitators of adaptation in the overall social-ecological vulnerability assessment metric.

In the context of community characteristics, all three case study communities had relatively good social capital scores reflected by attributes such as a high rate of volunteering (St Helens), low proportion of unoccupied dwellings (Geraldton and Bowen), and relatively stable population size (Geraldton and Bowen). Utilizing these existing assets can help to streamline the adaptation process, particularly for adaptation strategies that require labor supply or secure local markets. Adaptations to improve public education and communication of the benefits of aquaculture and renewable energy would also benefit from a stable population. Similarly, capitals contributing to high vulnerability can indicate where barriers to adaptation may exist and where measures to remediate can be of greatest benefit.

The explicit consideration of social-ecological vulnerability in this study has integrated climate change drivers and impacts, including biological sensitivity, with an assessment of the community's capacity to adapt. This type of integrated assessment is necessary 
to allow a differentiation between high ecological sensitivity and high vulnerability. Following the impacts of a severe tropical cyclone on the Great Barrier Reef, Marshall et al. (2013) found that the commercial fishers and marine tourism operators that were most sensitive to cyclonic impacts were not necessarily the most vulnerable. Sensitivity was found to be offset by socioeconomic adaptive capacities. Similar results have been found in the current study with Geraldton producing the highest ecological vulnerability scores while also having relatively high adaptive capacity and relatively low social-ecological vulnerability to marine climate change. Very high climate and integrated species exposure were the main drivers contributing to high ecological vulnerability in Geraldton whereas lower resource dependence and generally moderate capital scores resulted in the lower social-ecological vulnerability. In other words, Geraldton was identified as the community most likely to be able to cope with climate change impacts because of the existence of other resources, such as skills, education, and financial wealth that enable communities to adapt to change. Nevertheless, heatwaves, changes in ocean currents and the location and timing of storms will likely mean an ongoing need for adaptation in Geraldton is, and will remain, a priority for marine industries and the local government. The need for marine sectors in Geraldton to adapt to climate change impacts is likely to arise through impacts on the rock lobster (Caputi and Brown 1993, Caputi et al. 2010) and scallop fishing industries (Mueller et al. 2012), species selection in the developing finfish aquaculture sector (John Eyres, WA Department of Fisheries, personal communication) and marine tourism (Abdo et al. 2012). To maintain sustainable livelihoods in existing industries into the future marine impacts must continue to be considered in the management of marine sectors and resources in Western Australia, and elsewhere.

A comparison of the social-ecological vulnerability in the three case study communities showed that Bowen was particularly vulnerable because of its high resource dependence and exposure to climate change. In this study, low population sizes in St Helens and Bowen were also found to correspond to low natural (through past and current use) and human capital and higher resource dependence. Similar results have been found in studies focusing on rural resource dependent communities including graziers in northern Queensland (Marshall et al. 2011) and rural and resource-based communities in Canada (McLeman et al. 2011), where a reduction in resource dependence can enhance adaptive capacity. Another Canadian study found fishing dependent communities consistently had low in-migration, high rates of poverty and unemployment, and low family income and educational attainment (Stedman et al. 2004). However, Stedman et al. found the specific resource sector involved was also important in predicting the outcome of reduced resource dependence with significant differences between resource sectors (energy, agriculture, forestry, and fisheries). Positive outcomes were generally found for human capital in energy and agriculturebased communities while variable outcomes were found for communities reliant on forestry.

One of the reasons for adaptation is to reduce socioeconomic vulnerability and improve adaptive capacity to cope with climate change impacts (Smit and Wandel 2006, Engle 2011). A focus on reducing resource dependence and increasing social and human capital will be critical to achieving this. However, care must be taken in reducing resource dependence given the potential differences in adaptive capacity conferred to the community from different resource sectors, such as mining, forestry, and fisheries (Stedman et al. 2004) and, in the coastal communities in the current study, the heavy reliance on natural resources for a large proportion of employment. Additional employment opportunities in independent industries, such as tourism and education, and a willingness to adapt must also exist for adaptations of this kind to be successful (Freudenburg and Gramling 1998). Adaptations that increase and support research in "up-and-coming" industries such as aquaculture and renewable energy production can assist in achieving reduced resource dependence without substantial loss of employment by promoting additional education or skill development and providing new employment opportunities. Encouraging increased tourism through improved marketing and promotion can also maintain or improve population and employment rates by providing tourism-related employment (Whitsunday Regional Council 2013). The City of Greater Geraldton Economic Development Strategy (2013-2023) has recognized the need to shift toward a diversified and sustainable economy based on knowledge-based industries. Economic diversification can be achieved through new and emerging industries and promoting tourism using more appealing branding of Geraldton as a tourist destination. Suggested outcomes include higher labor force participation, industry diversification and capacity building, and higher productivity of core industries such as agriculture, fisheries, and logistics (City of Greater Geraldton 2013). These adaptations could also be expected to indirectly reduce the proportion of unoccupied dwellings (by sustaining population) and the need for social assistance (through employment), which would contribute to improved social and human capital.

Barriers to adaptation may be mitigated or eliminated through trade-offs or substitution of one capital for another (Farrington et al. 1999) but this is by no means simple to achieve. For instance, trading off between capitals may create conflict on how funds or skills should be used and between short- and long-term goals (Dessai and Hulme 2007, Adger et al. 2009). In Bowen, the shortterm closure of cyclone-damaged reefs could cause such conflict by trading off between short- and long-term goals for employment in the marine sector. The short-term closure of cyclone-damaged reefs would force fishers to shift fishing effort elsewhere to maintain adequate profits, but may result in longterm fisheries sustainability and management outcomes.

Substitution and trading off between capitals can result in conflict between short- and long-term outcomes but also create tension between community and state- or federal-level institutions if the responsibilities of the community versus these agencies are unclear. For example, the moderate availability of physical capital in Geraldton may constrain the development of new aquaculture and renewable energy ventures in the area. Investing in physical capital using the relatively large financial resources (financial capital) of Western Australia could help fund new aquaculture and renewable energy infrastructure in Geraldton. However, the decision to progress with such an adaptation rests with the state government authorities and their priorities may not line up with local government infrastructure priorities. In Bowen adaptations that encourage participation in scientific research, and ensure balanced representation on comanagement and industry bodies 
could be perceived as community or state-based responsibilities. Where external support (funding and management) is necessary for implementation success, the role of the state becomes more important. In these situations, explicit discussion and agreement of support for potential adaptation strategies must be obtained prior to the final selection of adaptation strategies, with discussions being inclusive of both community and state-based representatives.

Extreme climate change impacts can also act as barriers to adaptation and improved livelihoods, particularly in the shortterm if damage is so severe that previously identified adaptations cannot be carried out. For example, following the extreme marine heatwave of 2010/2011 (e.g., Pearce and Feng 2013, Wernberg et al. 2013), the scallop fishery at the Abrolhos Islands was decimated and is yet to show any signs of recovery (Caputi et al. 2014b). Adaptations within this fishery would therefore not be practical and alternative measures, such as shifting to a different fishery or industry are the only options until the fishery recovers. In the long-term, it is expected that barriers arising from climate change impacts will diminish as communities learn to plan for climate extremes in advance and adapt to relative climate uncertainty (Hodgkinson et al. 2014).

Adaptation is a process that has numerous stages, from issue identification through to the implementation of an adaptive management cycle, and barriers to adaptation may arise at any point and may be driven by external factors. For example, perception of climate change as being of low risk and removed from direct personal experience (e.g., Bord et al. 1998, Kirby 2004) can result in a lack of understanding and challenges in the identification and implementation of adaptations. Other factors, such as willingness to adapt and the need for policy or institutional reform (Dessai and Hulme 2007), can also contribute to bottlenecks around the discussion of adaptation options and pathways. The methods developed here can be useful in starting the process of issue identification and assist progress toward implementation success in marine social-ecological systems.

Consideration must be given to potential biases arising from the selection of indicators for sustainable livelihoods analysis capital assessment (Smit and Wandel 2006), and to the overall challenges that complex social-ecological systems present when selecting or building indicator frameworks (Davidson et al. 2013). This is particularly the case with natural capital in this study, where only one indicator was used and that focused on employment as a proxy for monetary or production value. Employment was used as a measure because it was the only information available for all case studies and if alternative measures are available in future studies they should be considered. For example, the inclusion of recreational and traditional fishing as indicators for resource dependence would likely improve the accuracy of the overall social-ecological vulnerability (SEV) measure.

Ideally indicators included in natural capital would include marine resource specific measures such as primary productivity (tonnes per area) and ecosystem integrity (pristine versus depleted) (State of the Environment Committee 2011). However, such indicators would provide most benefit in a comparison of localities if they were site-specific rather than proxies from other locations. This information was not available for all three case study locations and further data collection for these indicators was not within the scope of the current study. In addition, the indicators that currently represent the other capitals would be more case specific if complemented with marine specific indicators like availability of boat ramps/access points (physical), marine science and fishing knowledge, number of years in fishing sector (human), and cultural identification with fishing (social). Other issues that arise using the selected set of indicators to measure the different capitals include the depreciation (or appreciation) of capitals over time (Smit and Wandel 2006) and the consideration of weightings for different capitals that are in line with case specific goals for adaptation (Dessai and Hulme 2007).

The coastal communities in this study all possess multiple marine resource sectors and are relatively heavily dependent on one or more of the marine sectors for employment. An in-depth analysis of the differences between the resource sectors and their community-level adaptive capacity and social-ecological vulnerability must be considered during future adaptation planning. This may provide a richer explanation for the socialecological vulnerability of Bowen, and similar multiresource sector communities in Queensland and Australia. The estimation, characterization, and comparison of community social-ecological vulnerability have been valuable in identifying enablers and barriers to the successful implementation of adaptations. If traction can be gained in decision-making agencies such as local and state governments, insights into the vulnerability characteristics gained in this study will help prioritize adaptation actions. For example, regions that are dominated by biophysical climate change challenges, e.g., rapidly rising sea surface temperatures, but that have strong socioeconomic adaptive capacity might prioritize longer term strategies that achieve economic stability within this time frame. If regions experience challenges mainly in the socioeconomic domain, their priority might be to strengthen adaptive capacity in the short term to achieve a greater capacity to deal with longer term ecological vulnerability.

The codependency framework adopted in this study, connecting the ecological system to the socioeconomic domain, has been designed for ease of implementation and use by practitioners and the general public alike. The approach uses free and publicly available data, and aims to ultimately assist communities in better understanding their relative strengths and weaknesses that affect successful adaptation to climate change. The Coastal Climate Blueprint web site developed for the purpose of information provision as well as creating a community blueprint for climate change adaptation is also freely available. The methods applied in this study are accessible on the web site and can be easily adapted to adaptation planning focusing on nonclimate impacts and change applications in a variety of environmental settings, i.e., rural or urban, and scales, i.e., city, state, country.

Responses to this article can be read online at: http://www.ecologyandsociety.org/issues/responses. php/7509 


\section{Acknowledgments:}

This study was funded by the Fisheries Research and Development Corporation (FRDC 2010/542). G. Pecl was funded by an ARC Future Fellowship. The role of OceanWatch and SeaNet officers was invaluable throughout the community visits. We would specifically like to thank Lowri Pryce, Anita Paulsen, Dave Schubert, Jay Shoesmith, and Cassie Price for all their help. We would like to thank all survey respondents and contacts in St Helens, Bowen, and Geraldton for their valuable insights and willingness to participate.

\section{LITERATURE CITED}

Abdo, D. A., L. M. Bellchambers, and S. N. Evans. 2012. Turning up the heat: increasing temperature and coral bleaching at the high latitude coral reefs of the Houtman Abrolhos Islands. PLoS ONE 7(8):e43878. http://dx.doi.org/10.1371/journal.pone.0043878

Adger, W. N. 2001. Social capital and climate change. Working Paper 8. Tyndall Centre for Climate Change Research, University of East Anglia, Norwich, UK.

Adger, W. N. 2006. Vulnerability. Global Environmental Change 16(3):268-281. http://dx.doi.org/10.1016/j.gloenvcha.2006.02.006

Adger, W. N., N. W. Arnell, and E. L. Tompkins. 2005. Successful adaptation to climate change across scales. Global Environmental Change 15:77-86. http://dx.doi.org/10.1016/j.gloenvcha.2004.12.005

Adger, W. N., J. Barnett, K. Brown, N. Marshall, and K. O’Brien. 2013. Cultural dimensions of climate change impacts and adaptation. Nature Climate Change 3:112-117. http://dx.doi. org/10.1038/nclimate1666

Adger, W. N., S. Dessai, M. Goulden, M. Hulme, I. Lorenzoni, D. R. Nelson, L. O. Naess, J. Wolf, and A. Wreford. 2009. Are there social limits to adaptation to climate change? Climatic Change 93:335-354. http://dx.doi.org/10.1007/s10584-008-9520$\underline{z}$

Adger, W. N., S. Huq, K. Brown, D. Conway, and M. Hulme. 2003. Adaptation to climate change in the developing world. Progress in Development Studies 3(3):179-195. http://dx.doi. org/10.1191/1464993403ps060oa

Allison, E. H., and B. Horemans. 2006. Putting the principles of the sustainable livelihoods approach into fisheries development policy and practice. Marine Policy 30:757-766. http://dx.doi. org/10.1016/j.marpol.2006.02.001

Armitage, D. 2005. Adaptive capacity and community-based natural resource management. Environmental Management 35 (6):703-715. http://dx.doi.org/10.1007/s00267-004-0076-z

Armitage, D., and R. Plummer, editors. 2010. Adaptive capacity and environmental governance. Springer, Berlin, Germany. http:// dx.doi.org/10.1007/978-3-642-12194-4

Australian Bureau of Statistics (ABS). 2003. Census of population and housing: population growth and distribution, Australia 2001. Commonwealth of Asutralia, Canberra, ACT, Australia. [online] URL: http://www.ausstats.abs.gov.au/Ausstats/subscriber.nsf/Lookup/ D9379A6FFA24473CCA256D470005CC1C/\$File/20350_2001.pdf
Australian Bureau of Statistics (ABS). 2006. 2006 Census data. Commonwealth of Asutralia, Canberra, ACT, Australia. [online] URL: http://www.abs.gov.au/websitedbs/censushome.nsf/home/ historicaldata2006? opendocument\&navpos $=280$

Australian Bureau of Statistics (ABS). 2011. Data \& analysis. Commonwealth of Asutralia, Canberra, ACT, Australia. [online] URL: http://www.abs.gov.au/websitedbs/censushome.nsf/home/ data?opendocument $\&$ navpos $=200$

Australian Government. 2007. Climate change adaptation actions for local government. Department of Climate Change, Canberra, Australia.

Australian Institute of Marine Science (AIMS). 2012. The AIMS index of marine industry. AIMS, Townsville, Australia. [online] URL: http://www.aims.gov.au/documents/30301/23122/The+AIMS+ Index + of +Marine+Industry+2012.pdf/d0fc7dc9-ae98-4e79$\underline{\mathrm{a} 0 \mathrm{~b} 2-271 \mathrm{af} 9 \mathrm{~b} 5454 \mathrm{f}}$

Barnett, J., S. Graham, C. Mortreux, R. Fincher, E. Waters, and A. Hurlimann. 2014. A local coastal adaptation pathway. Nature Climate Change 4:1103-1108. http://dx.doi.org/10.1038/NCLIMATE2383

Bord, R. J., A. Fisher, and R. E. O’Connor. 1998. Public perceptions of global warming: United States and international perspectives. Climate Research 11:75-84. http://dx.doi.org/10.3354/ cr011075

Brander, K. M. 2007. Global fish production and climate change. Proceedings of the National Academy of Sciences 104 (50):19709-19714. http://dx.doi.org/10.1073/pnas.0702059104

Brooks, N., and W. N. Adger. 2005. Assessing and enhancing adaptive capacity. Pages 165-181 in B. Lim, editor. Adaptation policy framework. United Nations Development Programme, New York, New York, USA.

Brown, P. R., R. Nelson, B. Jacobs, P. Kokic, J. Tracey, M. Ahmed, and P. DeVoil. 2010. Enabling natural resource managers to selfassess their adaptive capacity. Agricultural Systems 103:562-568. http://dx.doi.org/10.1016/j.agsy.2010.06.004

Burnley, I. H., and P. A. Murphy. 2002. Change, continuity or cycles: the population turnaround in New South Wales. Journal of Population Research 19(2):137-154. http://dx.doi.org/10.1007/ BF03031974

Caputi, N., and R. S. Brown. 1993. The effect of environment on puerulus settlement of the western rock lobster (Panulirus cygnus) in Western Australia. Fisheries Oceanography 2:1-10. http://dx. doi.org/10.1111/j.1365-2419.1993.tb00007.x

Caputi, N., M. Feng, A. Pearce, J. Benthuysen, A. Denham, Y. Hetzel, R. Matear, G. Jackson, B. Molony, L. Joll, and A. Chandrapavan. 2014a. Management implications of climate change effects on fisheries in Western Australia. FRDC report 2010/535. Fisheries Research \& Development Corporation, Deakin West, Australia.

Caputi, N., G. Jackson, and A. Pearce. 2014b. The marine heat wave off Western Australia during the summer of 2010/11 - 2 years on. Fisheries Research Report, Department of Fisheries, Government of Western Australia. 
Caputi, N., R. Melville-Smith, S. de Lestang, A. Pearce, and M. Feng. 2010. The effect of climate change on the western rock lobster (Panulirus cygnus) fishery of Western Australia. Canadian Journal of Fisheries and Aquatic Sciences 67:85-96. http://dx.doi. org/10.1139/F09-167

City of Greater Geraldton. 2013. Greater Geraldton economic development strategy (2013-2023). City of Greater Geraldton, Western Australia. [online] URL: http://www.cgg.wa.gov.au/ Profiles/cgg/Assets/ClientData/Document-Centre/Council/Strategic/ Greater Geraldton Economic Development Strategy 2013-2023. pdf

Costanza, R., R. d'Arge, R. de Groot, S. Farber, M. Grasso, B. Hannon, K. Limburg, S. Naeem, R. V. O’Neil, J. Paruelo, R. G. Raskin, P. Sutton, and M. van den Belt. 1997. The value of the world's ecosystem services and natural capital. Nature 387:253-260. http://dx.doi.org/10.1038/387253a0

Council of Australian Governments (COAG). 2007. National climate change adaptation framework. [online] URL: http://www. environment.gov.au/climate-change/adaptation/publications/nationalclimate-change-adaptation-framework

CSIRO. 2008. Projecting Australian climate change. The Garnaut Climate Change Review. CSIRO, Aspendale, Victoria. [online] URL: http://www.garnautreview.org.au/pdf/Garnaut Chapter5. pdf

Daley, J., and A. Lancy. 2011. Investing in regions: making a difference. The Grattan Institute, Melbourne, Australia.

Darnhofer, I., S. Bellon, B. Dedieu, and R. Milestad. 2010. Adaptiveness to enhance the sustainability of farming systems. A review. Agronomy and Sustainable Development 30:545-555. http:// dx.doi.org/10.1051/agro/2009053

Davidson, J. L., E. I. van Putten, P. Leith, M. Nursey-Bray, E. M. Madin, and N. J. Holbrook. 2013. Toward operationalizing resilience concepts in Australian marine sectors coping with climate change. Ecology and Society 18(3): 4. http://dx.doi. org/10.5751/ES-05607-180304

De Haan, L. 2012. The livelihood approach: a critical exploration. Erdkunde 66(4):345-357. http://dx.doi.org/10.3112/erdkunde.2012.04.05

Dessai, S., and M. Hulme. 2007. Assessing the robustness of adaptation decisions to climate change uncertainties: a case study on water resources management in the East of England. Global Environmental Change 17(1):59-72. http://dx.doi.org/10.1016/j. gloenvcha.2006.11.005

Ekstrom, J. A., and S. C. Moser. 2013. Institutions as key element to successful climate adaptation processes: results from the San Fransisco Bay Area. Pages 97-113 in S. C. Moser and M. T. Boykoff, editors. Successful adaptation to climate change: linking science and policy in a rapidly changing world. Routledge, New York, New York, USA.

Ellis, F. 2000. Rural livelihoods and diversity in developing countries. Oxford University Press, Oxford, UK.

Elrick-Barr, C. E., B. L. Preston, D. C. Thomsen, and T. F. Smith. 2014. Toward a new conceptualization of household adaptive capacity to climate change: applying a risk governance lens. Ecology and Society 19(4): 12. http://dx.doi.org/10.5751/ ES-06745-190412
Engle, N. L. 2011. Adaptive capacity and its assessment. Global Environmental Change 21(2):647-656. http://dx.doi.org/10.1016/ j.gloenvcha.2011.01.019

Farrington, J., D. Carney, C. Ashley, and C. Turton. 1999. Sustainable livelihoods in practice: early application of concepts in rural areas. Natural Resource Perspectives 42.

Folke, C. 2006. Resilience: the emergence of a perspective for social-ecological systems analyses. Global Environmental Change 16:253-67. http://dx.doi.org/10.1016/j.gloenvcha.2006.04.002

Food and Agriculture Organization (FAO). 2013. Report of the FAO/PaCFA Expert Workshop on Assessing Climate Change Vulnerability in Fisheries and Aquaculture: Available Methodologies and their Relevance for the Sector. Windhoek, Namibia, 8-10 April 2013. FAO Fisheries and Aquaculture Report No. 1047. FAO, Rome, Italy.

Freudenberg, W. R., and R. Gramling. 1998. Linked to what? Economic linkages in an extractive economy. Society and Natural Resources 11:569-586. http://dx.doi.org/10.1080/08941929809381103

Frick, J., F. G. Kaiser, and M. Wilson. 2004. Environmental knowledge and conservation behaviour: exploring prevalence and structure in a representative sample. Personality and Individual Differences 37:1597-1613. http://dx.doi.org/10.1016/j.paid.2004.02.015

Goodman, L. A. 1961. Snowball sampling. Annals of Mathematical Statistics 32(1):148-170. http://dx.doi.org/10.1214/ aoms/1177705148

Gunderson, L. H. 2000. Ecological resilience - in theory and application. Annual review of Ecology and Systematics 31:425-439. http://dx.doi.org/10.1146/annurev.ecolsys.31.1.425

Gurran, N., and E. Blakely. 2007. Suffer a sea change? Contrasting perspectives towards urban policy and migration in coastal Australia. Australian Geographer 38(1):113-131. http://dx.doi. org/10.1080/00049180601175899

Hobday, A. J., E. S. Poloczanska, and R. J. Matear. 2008. Implications of climate change for Australian fisheries and aquaculture: a preliminary assessment. Department of Climate Change, Commonwealth of Australia.

Hodgkinson, J. H., A. J. Hobday, and E. A. Pinkard. 2014. Climate adaptation in Australia's resource-extraction industries: ready or not? Regional Environmental Change 14:1663-1678. http://dx.doi.org/10.1007/s10113-014-0618-8

Holbrook, N. J., and J. E. Johnson. 2014. Climate change impacts and adaptation of commercial marine fisheries in Australia: a review of the science. Climatic Change 124:703-715. http://dx.doi. org/10.1007/s10584-014-1110-7

Howden, S. M., J.-F. Soussana, F. N. Tubiello, N. Chhetri, M. Dunlop, and H. Meinke. 2007. Adapting agriculture to climate change. Proceedings of the National Academy of Sciences 104:19691-19696. http://dx.doi.org/10.1073/pnas.0701890104

Hulme, M. 2009. Why we disagree about climate change: understanding controversy, inaction and opportunity. Cambridge University Press, Cambridge, UK. http://dx.doi.org/10.1017/ CBO9780511841200 
Intergovernmental Panel on Climate Change (IPCC). 2001. Climate change 2001: impacts, adaptation, and vulnerability. Contribution of Working Group II to the Third Assessment Report of the Intergovernmental Panel on Climate Change. J. J. McCarthy, O. F. Canziani, N. A. Leary, D. J. Dokken, and K. S. White, editors. Cambridge University Press, Cambridge, UK.

Intergovernmental Panel on Climate Change (IPCC). 2007. Climate change 2007: impacts, adaptation and vulnerability. Contributions of Working Group II to the Fourth Assessment report of the International Panel on Climate Change. M. L. Parry, O. F. Canziani, J. P. Palutikof, P. J. van der Linden, and C. E. Hanson, editors. Cambridge University Press, Cambridge, UK.

Kalaugher, E., J. F. Bornman, A. Clark, and P. Beukes. 2013. An integrated biophysical and socio-economic framework for analysis of climate change adaptation strategies: the case of a New Zealand dairy farming system. Environmental Modelling \& Software 39:176-187. http://dx.doi.org/10.1016/j.envsoft.2012.03.018

Kirby, A. 2004. Britons unsure of climate costs. BBC News Online, 24 July. [online] URL: http://news.bbc.co.uk/2/hi/science/ nature/3934363.stm

Lawes, R. A., and R. S. Kingwell. 2012. A longitudinal examination of business performance indicators for droughtaffected farms. Agricultural Systems 106:94-101. http://dx.doi. org/10.1016/j.agsy.2011.10.006

Marshall, N. A., I. J. Gordon, and A. J. Ash. 2011. The reluctance of resource-users to adopt seasonal climate forecasts to enhance resilience to climate variability on the rangelands. Climatic Change 107:511-529. http://dx.doi.org/10.1007/s10584-010-9962y

Marshall, N. A., S. E. Park, W. N. Adger, K. Brown, and S. M. Howden. 2012. Transformational capacity and the influence of place and identity. Environmental Research Letters 7:034022. http://dx.doi.org/10.1088/1748-9326/7/3/034022

Marshall, N. A., R. C. Tobin, P. A. Marshall, M. Gooch, and A. J. Hobday. 2013. Social vulnerability of marine resource users to extreme weather events. Ecosystems 16(5):797-809. http://dx.doi. org/10.1007/s10021-013-9651-6

McAllister, R. R. J., T. F. Smith, C. E. Lovelock, D. Low Choy, A. J. Ash, and J. McDonald. 2014. Adapting to climate change in South East Queensland, Australia. Regional Environmental Change 14:429-433. http://dx.doi.org/10.1007/s10113-013-0505-8

McLeman, R. A., M. Brklacich, M. Woodrow, K. Vodden, P. Gallagher, and R. Sander-Regier. 2011. Opportunities and barriers for adaptation and local adaptation planning in Canadian rural and resource-based communities. Pages 449-459 in J. Ford and L. Berrang-Ford, editors. Climate change adaptation in developed nations: from theory to practice. Springer, New York, New York, USA. http://dx.doi.org/10.1007/978-94-007-0567-8 33

McNiven, I. 2004. Saltwater people: spiritscapes, maritime rituals and the archaeology of Australian indigenous seascapes. World Archaeology 35(3):329-349. http://dx.doi.org/10.1080/00438240$\underline{42000185757}$

Mueller, U., M. Kangas, E. Sporer, and N. Caputi. 2012. Variability in the spatial and temporal distribution of the saucer scallop, Amusium balloti, in Shark Bay management implications. Marine and Freshwater Research 63:1152-1164. http://dx.doi. org/10.1071/MF12051

Nelson, D. R., W. N. Adger, and K. Brown. 2007. Adaptation to environmental change: contributions of a resilience framework. Annual Review of Environment and Resources 32:395-419. http:// dx.doi.org/10.1146/annurev.energy.32.051807.090348

Nursey-Bray, M., G. T. Pecl, S. Frusher, C. Gardner, M. Haward, A. J. Hobday, S. Jennings, A. E. Punt, H. Revill, and I. van Putten. 2012. Communicating climate change: climate change risk perceptions and rock lobster fishers, Tasmania. Marine Policy 36:753-759. http://dx.doi.org/10.1016/j.marpol.2011.10.015

O'Brien, K., S. Eriksen, L. Sygna, and L. O. Naess. 2006. Questioning complacency: climate change impacts, vulnerability and adaptation in Norway. AMBIO 35(2):50-56. http://dx.doi. org/10.1579/0044-7447(2006)35[50:QCCCIV]2.0.CO;2

Organisation for Economic Co-operation and Development (OECD). 2010. Executive summary. Pages 17-28 in Cities and climate change. OECD Publishing, Paris, France. http://dx.doi. org/10.1787/9789264091375-4-en

Pearce, A. F., and M. Feng. 2013. The rise and fall of the "marine heat wave" off Western Australia during the summer of 2010/2011. Journal of Marine Systems 111-112:139-156. http:// dx.doi.org/10.1016/j.jmarsys.2012.10.009

Pecl, G. T., T. M. Ward, Z. A. Doubleday, S. Clarke, J. Day, C. Dixon, S. Frusher, P. J. Gibbs, A. J. Hobday, N. Hutchinson, S. Jennings, K. Jones, X. Li, D. Spooner, and R. Stoklosa. 2014. Rapid assessment of fisheries species sensitivity to climate change. Climatic Change 127:505-520. http://dx.doi.org/10.1007/s10584-014-1284$\underline{Z}$

Pihkala, T., V. Harmaakorpi, and S. Pekkarinen. 2007. The role of dynamic capabilities and social capital in breaking socioinstitutional inertia in regional development. International Journal of Urban and Regional Research 31:836-852. http://dx.doi. org/10.1111/j.1468-2427.2007.00757.x

Regional Australia Institute. 2013. Insight: Australia's regional competitiveness index. Regional Australia Institute, Barton, Australia. [online] URL: http://www.regionalaustralia.org.au/ wp-content/uploads/2013/06/RAI-InSight-Major-Findings-130624-5. pdf

Renn, O., A. Klinke, and M. van Asselt. 2011. Coping with complexity, uncertainty and ambiguity in risk governance: a synthesis. AMBIO 40(2):231-246. http://dx.doi.org/10.1007/ $\underline{\mathrm{s} 13280-010-0134-0}$

Risbey, J., M. Kandlikar, H. Dowlatabadi, and D. Graetz. 1999. Scale, context, and decision-making in agricultural adaptation to climate variability and change. Mitigation and Adaptation Strategies for Global Change 4:137-165. http://dx.doi. org/10.1023/A:1009636607038

Ritchie, J. W., G. Y. Abawi, S. C. Dutta, T. R. Harris, and M. Bange. 2004. Risk management strategies using seasonal climate forecasting in irrigated cotton production: a tale of stochastic dominance. Australian Journal of Agricultural and Resource Economics 48:65-93. http://dx.doi.org/10.1111/j.1467-8489.2004.00236. 
Roessig, J. M., C. M. Woodley, J. J. Cech Jr., and L. J. Hansen. 2004. Effects of global climate change on marine and estuarine fishes and fisheries. Reviews in Fish Biology and Fisheries 14:251-275. http://dx.doi.org/10.1007/s11160-004-6749-0

Scoones, I. 1998. Sustainable rural livelihoods: a framework for analysis. IDS Working Paper 72. Institute of Development Studies, University of Sussex, Brighton, UK.

Smit, B., and J. Wandel. 2006. Adaptation, adaptive capacity and vulnerability. Global Environmental Change 16:282-292. http://dx. doi.org/10.1016/j.gloenvcha.2006.03.008

Spillman, C. M., and A. J. Hobday. 2014. Dynamical seasonal forecasts to aid salmon farm management in a climate hotspot. Climate Risk Management 1:25-38. http://dx.doi.org/10.1016/j. crm.2013.12.001

Stafford-Smith, M., L. Horrocks, A. Harvey, and C. Hamilton. 2011. Rethinking adaptation for a $4^{\circ} \mathrm{C}$ world. Philosophical Transactions of the Royal Society A, Mathematical, Physical and Engineering Sciences 369:196-216. http://dx.doi.org/10.1098/ $\underline{\text { rsta.2010.0277 }}$

State of the Environment Committee. 2011. Australia state of the environment 2011. Independent report to the Australian Government Minister for Sustainability, Environment, Water, Population and Communities. Australian State Environment Committee, Canberra, Australia. [online] URL: http://www. environment.gov.au/science/soe/2011-report/download

Stedman, R. C., J. R. Parkins, and T. M. Beckley. 2004. Resource dependence and community well-being in rural Canada. Rural Sociology 69(2):213-234.

Stenekes, N., I. Reeve, R. Kancans, R. Stayner, L. Randall, and K. Lawson. 2012. Revised indicators of community vulnerability and adaptive capacity across the Murray-Darling Basin: a focus on irrigation in agriculture. ABARES report to client prepared for the Murray-Darling Basin Authority, Canberra, Australia.

Taylor, C. R. 2003. The role of risk versus the role of uncertainty in economic systems. Agricultural Systems 75:251-264. http://dx. doi.org/10.1016/S0308-521X(02)00068-9

The Climate Institute 2013. Climate of the nation 2013: Australian attitudes on climate change. The Climate Institute, Sydney, Australia. [online] URL: http://www.climateinstitute.org.au/ verve/ resources/TCI ClimateOfTheNation2013 web.pdf

Tompkins, E. L., and W. N. Adger. 2004. Does adaptive management of natural resources enhance resilience to climate change? Ecology and Society 9(2): 10. [online] URL: http://www. ecologyandsociety.org/vol9/iss2/art10/

van Putten, E. I., S. J. Metcalf, S. D. Frusher, N. A. Marshall, and M. Tull. 2014. Transformation of coastal communities: Where is the marine sector heading? Australian Journal of Regional Studies 20(2):286-324.

Vincent, K. 2007. Uncertainty in adaptive capacity and the importance of scale. Global Environmental Change 17:12-24. http://dx.doi.org/10.1016/j.gloenvcha.2006.11.009
Wall, G. 1998. Implications of global climate change for tourism and recreation in wetland areas. Climatic Change 40:371-389. http://dx.doi.org/10.1023/A:1005493625658

Welch, D. J., T. Saunders, J. Robins, A. Harry, J. Johnson, J. Maynard, R. Saunders, G. Pecl, B. Sawynok, and A. Tobin. 2014. Implications of climate change impacts on fisheries resources of northern Australia. Part 1: Vulnerability assessment and adaptation options. FRDC Project No: 2010/565. Fisheries Research \& Development Corporation, Deakin West, Australia.

Wernberg, T., D. A. Smale, F. Tuya, M. S. Thomsen, T. J. Langlois, T. de Bettignies, S. Bennett, and C. S. Rousseaux. 2013. An extreme climatic event alters marine ecosystem structure in a global biodiversity hotspot. Nature Climate Change 3:78-82. DOI:10.1038/NCLIMATE1627. http://dx.doi.org/10.1038/

\section{NCLIMATE1627}

Whitsunday Regional Council. 2013. Bowen Collinsville Enterprise. Whitsunday Regional Council, Proserpine, Australia. [online] URL: http://www.whitsunday.qld.gov.au/economicdevelopment

Wolf, J. 2011. Climate change adaptation as a social process. Pages 21-32 in J. Ford and L. Berrang-Ford, editors. Climate change adaptation in developed nations: from theory to practice. Springer, New York, New York, USA. http://dx.doi.org/10.1007/978-94-007-0567-8 2 
Appendix 1. Survey instrument used to gather data used in this study.

Establish which business interviewee is in that depends on marine resources

Which marine dependent economic activity are you engaged in?

How did you get involved in this activity (prompt - family business) ?

How long do you think you'll keep doing it?

Is your work in this job seasonal? i.e. do you do any other type of work throughout the year?

(If yes, what type of work)?

How much of your income is dependent on this activity?

How many people do you employ?

(and how many are family members)?

How much of you/your family time do you spend on this activity that is unpaid?

(prompt - average number of days you spend doing the books or repairs)

Has your income from this activity increased or decreased over the past 5 years?

Which particular local goods and services their business depends on and supplies to

Which sectors do you buy from for your business (prompt diesel - tackle - boat slipping) ?

Ask how much?

Which sectors do you sell to (prompt fish restaurant - processors)?

Ask how much

Aside from your own business activity, can you tell me which other local sectors are directly dependent on marine resources (prompt commercial fishing - tourism)?

\section{Sorts of things the affect their business in the SHORT term}

Which factors affect your business activity in the SHORT term?

(prompt price of fuel - exchange rate - price of fish - cold storage - offloading facilities)

Can you tell me which of these short term factors are likely to most affect your business?

Can you tell me how changes in the short term factors will affect your business?

Have any of the changes in short term factors affected your business in the past?

Do you expect they will affect you in the future?

Is there anything that can be done now to prevent these things from affecting you in the future?

Is there anything that local or state government can do now to prevent these things?

Things that they think will affect their business in the LONG term

Which factors affect your business activity in the long term?

(prompt government regulations - fish abundance - roads - offloading \& processing facilities)

Can you tell me which of these long term factors are likely to most affect your business?

Can you tell me how changes in the long term factors will affect your business?

Have any of the changes in long term factors affected your business in the past?

Do you expect they will affect you in the future?

Is there anything that you can do now to prevent these things from affecting you in the future?

Is there anything that local or state government can do now to prevent these things?

Things that affect them in the short and long term will have flow on effects in the local community (not only economic but also social) 
Can you tell me how/why the things that affect your business will affect others and other sectors in the community?

Is there anything that you/local/ state government can do to prevent these things from affecting the rest of the community? 